\title{
Assessment of extreme flood events in a changing climate for a long-term planning of socio-economic infrastructure in the Russian Arctic
}

\author{
Elena Shevnina $^{1,2}$, Ekaterina Kourzeneva $^{1}$, Viktor Kovalenko ${ }^{2}$, and Timo Vihma ${ }^{1}$ \\ ${ }^{1}$ Finnish Meteorological Institute, P.O. Box 503, 0010 Helsinki, Finland \\ ${ }^{2}$ Russian State Hydrometeorological University, Malookhtinsky prospect 98, 195196 Saint Petersburg, Russia
}

Correspondence to: Elena Shevnina (elena.shevnina@fmi.fi)

Received: 18 November 2015 - Discussion started: 15 January 2016

Revised: 11 April 2017 - Accepted: 16 April 2017 - Published: 23 May 2017

\begin{abstract}
Climate warming has been more acute in the Arctic than at lower latitudes and this tendency is expected to continue. This generates major challenges for economic activity in the region. Among other issues is the long-term planning and development of socio-economic infrastructure (dams, bridges, roads, etc.), which require climate-based forecasts of the frequency and magnitude of detrimental flood events. To estimate the cost of the infrastructure and operational risk, a probabilistic form of long-term forecasting is preferable. In this study, a probabilistic model to simulate the parameters of the probability density function (PDF) for multi-year runoff based on a projected climatology is applied to evaluate changes in extreme floods for the territory of the Russian Arctic. The model is validated by cross-comparison of the modelled and empirical PDFs using observations from 23 sites located in northern Russia. The mean values and coefficients of variation (CVs) of the spring flood depth of runoff are evaluated under four climate scenarios, using simulations of six climate models for the period 2010-2039. Regions with substantial expected changes in the means and $\mathrm{CVs}$ of spring flood depth of runoff are outlined. For the sites located within such regions, it is suggested to account for the future climate change in calculating the maximal discharges of rare occurrence. An example of engineering calculations for maximal discharges with $1 \%$ exceedance probability is provided for the Nadym River at Nadym.
\end{abstract}

\section{Introduction}

The economic importance of the Arctic has been increasingly recognized. Various governmental and commercial projects have been initiated internationally to develop the socio-economic infrastructure in the Arctic. Among others, there are projects for oil and gas fields in Mackenzie Valley, Canada (Mackenzie, 2017), in Prudhoe Bay, USA (Petrowiki, 2017), as well as in the Pechora and Yamal regions, Russia (Gazprom, 2017). To design hydraulic constructions, such as dams, bridges, roads, and pipelines, and to estimate the costs and risks of flood damage during the infrastructure's lifetime, information is needed on dangerous river discharges. These values are calculated from the uppertails of probability density functions (PDFs) for the maximal river runoff. The PDFs are usually constructed with three parametric distributions (e.g. Pearson type III or log Pearson type III) using the mean value, the coefficient of variation, and coefficient of skewness (Guideline SP33-101-2003, 2004; Bulletin 17-B, 1982). These parameters are calculated from observations with an assumption of stationarity in the climate and hydrological regimes (Thomas, 1985). It means that the values of the PDF parameters and runoff extremes do not change in the future or during the period of building construction.

A great number of weather anomalies and detrimental flood events have been observed during the last decade. Climate change has especially been recorded in the polar regions. Climate models predict a robust increase in precipitation over the Arctic and sub-Arctic (Collins et al., 2013; Laine et al., 2014). From October to March, precipitation 
in the Arctic is expected to increase by 35 and $60 \%$, under medium and high greenhouse gas (GHG) concentration pathways, respectively (RCP4.5 and 8.5), relative to the period 1986-2005 (IPCC, 2013). The projected precipitation increases from April to September under the same GHG pathways are 15 and $30 \%$, respectively. Due to climate warming and increased rainfall, annual-mean snowfall is projected to decrease over northern Europe and mid-latitude Asia, and to increase in northern Siberia, especially in winter (Krasting et al., 2013). Further, precipitation extremes are projected to increase, the climate model results being robust particularly for northern Eurasia in winter (Kharin et al., 2013; Toreti et al., 2013; Sillman et al., 2013). In Siberia these increases in precipitation will be accompanied by a decrease in the number of consecutive dry days (Sillman et al., 2013). Over northern Eurasia, the net precipitation (precipitation minus evapotranspiration) is also projected to increase during winter. The projected changes discussed above are likely with a high confidence (Collins et al., 2013), and therefore point to an urgent need to better evaluate the response of other components of the Arctic freshwater system, including terrestrial hydrology (Prowse et al., 2015).

There are two opposing opinions about climate change effects on the hydrological regime, in answer to the question: "is it necessary for managers and stakeholders to take account of climate change?" According to Milly et al. (2008) climate change effects are already substantial, and should be taken into account by planners and water managers. The opposing view projects doubts on climate change, and suggests one pay attention to the uncertainties due to the short observed time series (Lins and Cohn, 2011; Montanari and Koutsoyiannis, 2014; Serinaldi and Kilsby, 2015). We propose accounting for the future climate change effects on environmental risks even in the event that uncertainties can not be fully evaluated or are unknown. It is better to prevent disasters than to deal with their consequences, which may be more expensive than the initial investment. We consider that the changes in meteorological variables would remain noticeable in runoff, which is an element of general water balance. From a practical point of view, methods to evaluate the extreme flood events are required irrespective of the debates about the extent or reality of the climate change (Madsen et al., 2013).

In flood estimation two main approaches are usually applied. The deterministic approach is based on the combined use of a regional climate model (RCM) and a physically based rainfall-runoff hydrological model (Fig. 1). RCMs provide the future meteorological forcing variables with a high temporal resolution to drive a hydrological model that describes complex physical processes, such as infiltration, snow melting, and evapotranspiration. This allows for generating synthetic time series for river runoff (discharges) for individual watersheds, so that flood events with the required exceedance probability are then estimated from the simulated time series. Successful applications of this approach have been achieved in numerous studies (Veijalainen et al., 2010; Lawrence and Haddeland, 2011; Archeimer and Lindström, 2015). The large-scale rainfall-runoff models have also been used to assess changes in the future flood frequency by Lehner et al. (2006) for the European Arctic. The shortcoming of these studies is that the results are sensitive to algorithms calculating a pseudo-daily precipitation input from projected climatology provided by global circulation models (Verzano, 2009). The second approach to evaluating the hydrological response to the expected climate change is stochastic. Weather generators are used to simulate time series of meteorological forcing for physically based hydrological models (Kuchment and Gelfan, 2011). Thus, estimates of extreme hydrological events (floods or droughts) with the required exceedance probability are obtained for a climate scenario by producing the meteorological signal with the Monte Carlo method. Both approaches are usually applied for a single catchment. In regional-scale analysis, the runoff should be simulated for a set of watersheds. It makes the calculations extremely costly computationally, especially in the case of climate ensembles.

The approach presented in this paper could be named probabilistic (to distinguish from the stochastic modelling described above). This approach allows us to skip the generation of the runoff time series, since only PDF parameters are directly calculated from the meteorological statistics for the projected periods of 20-30 years (Fig. 1). These simulated PDF parameters are further used to evaluate the future runoff values with the required exceedance probability using theoretical distributions from the Pearson system (Elderton and Johnson, 1969). Since the probabilistic model simulates only three to four PDF parameters, this approach allows for a regional-scale assessment of detrimental hydrological events in the future to be easily performed, and to define the regions where the risks of damage for infrastructure increase.

The probabilistic approach used in this study combines statistical methods with elements of the theory of Markov processes. Both have been traditionally applied in hydrological engineering calculations to evaluate design floods (Kite, 1977; Benson, 1968; Kritsky and Menkel, 1946). The traditional frequency analysis of flood and drought requires the hydrological time series to estimate the PDF parameters and to calculate the runoff of the required exceedance probability. However, the PDF parameters can also be estimated from the meteorological variable statistics. The idea of performing the direct simulation of the PDF parameters from the climate projections (without the simulation of time series) is proposed by Kovalenko (1993). Kovalenko et al. (2010) simplified the basic probabilistic model for engineering hydrology, and Viktorova and Gromova (2008) applied this approach to produce a regional-scale assessment of the future drought extremes for the European part of Russia.

The main idea of the simplified method is the "quasistationarity" of the changing climate and hydrological regime for periods of $20-30$ years. This idea allows us to 


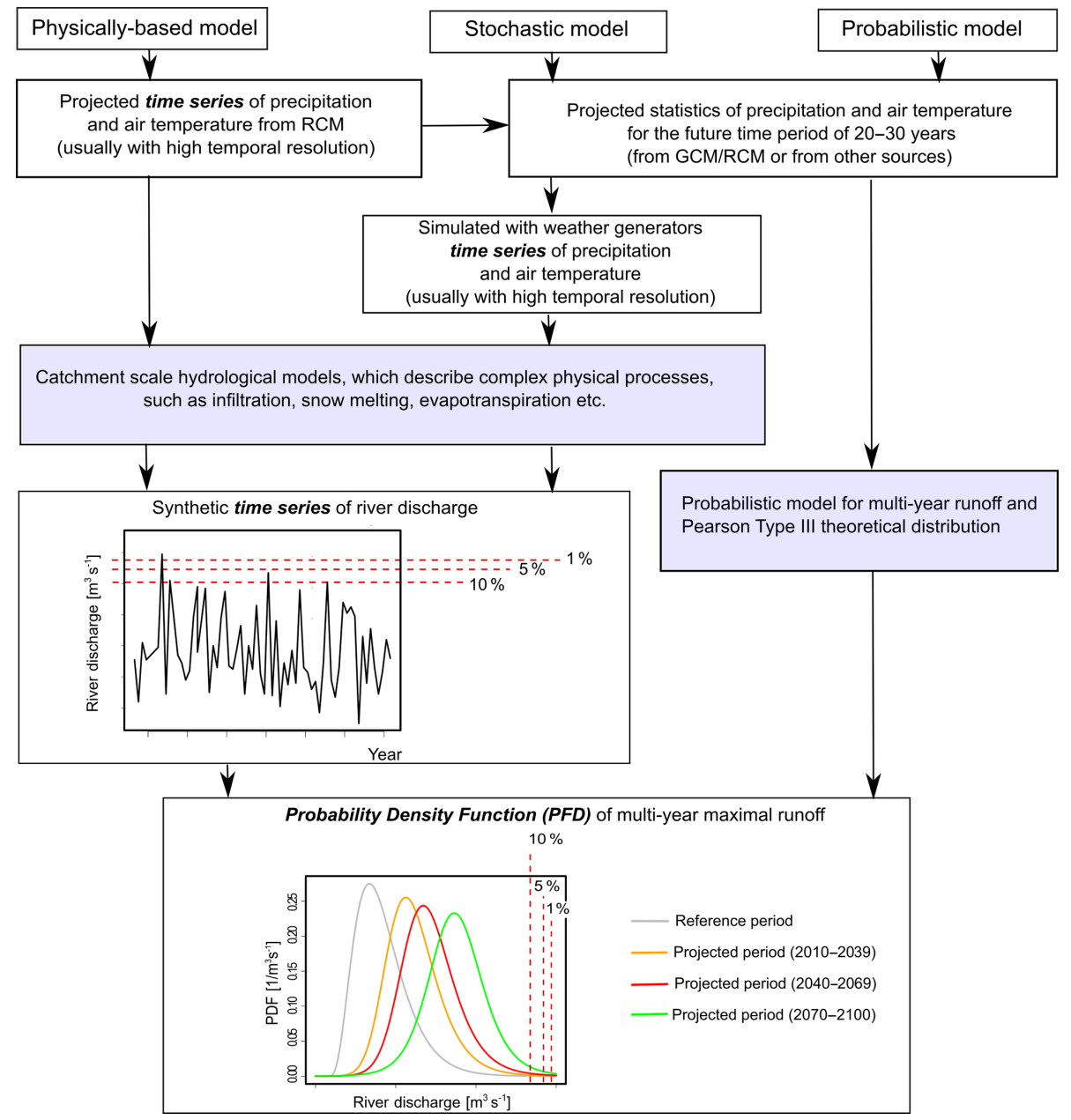

Figure 1. Three approaches to evaluate a hydrological response to the expected climate change.

represent the multi-year runoff statistically with a set of PDF parameters for the particular time window; the set is different for the past (or reference period) and the future (or projected period) climatology. Thus, climate change could be accounted for in the calculations of the runoff-tailed values, which are usually required for the assessment of risks in water management. The IPCC recommends climate projections are represented as multi-year means of the meteorological values for a period of 20-30 years (Pachauri and Reisinger, 2007), i.e. under the same quasi-stationarity assumption.

The probabilistic model provides a more economical way to produce the hydrological projections for the extremes on a regional scale. This is because of (i) a low number of forcing and simulated variables (only three to four statistics for climate and hydrological variables are needed), (ii) a low number of parameters (physical processes are described integrally by a lumped hydrological model), and (iii) relative simplicity in the regionally oriented parameterization. Furthermore, the probabilistic model does not require large spa- tially distributed datasets and may be applied to regions with poor data coverage, such as the Arctic.

The aim of this study is to perform a regional-scale assessment of the future extreme floods based on climate projections for the Russian Arctic. The novelty of the study includes two aspects. First, we present the method to assess the frequency and magnitude of extreme floods in a changing climate, adapted in this case to the Arctic territories. It could also be applied to other territories, as the regionally oriented parameterization is relatively simple. Second, the paper provides the projected changes in the mean values and coefficients of variation (CVs) of the flood spring depth of runoff under four climate scenarios for the Russian Arctic. The regional-scale assessments are based on the Special Report on Emissions Scenarios (SRES) and representative concentration pathway (RCP) scenarios. The regions are delineated, where the frequency and magnitude of floods are expected to change substantially. Maps include a warning for those regions where engineering calculations on extreme maximal discharges should be corrected to account for cli- 
mate change. An example of the engineering calculation of a maximal discharge of $1 \%$ exceedance probability for the Nadym River at Nadym is provided using the outputs of three climate models for the period 2010-2039.

\section{Methods and data}

The idea of the method used in this study is (i) to simulate the future PDF parameters of the multi-year peak runoff using the projected mean values for precipitation and air temperature, (ii) to construct the PDF with simulated parameters and a previously defined theoretical distribution (Pearson type III), and finally (iii) to calculate the maximal runoff with the required exceedance probability. This idea was used to perform the regional-scale assessment of the maximal runoff for the northern territories of Russia, where the peaks occur during the spring. On these territories, the peak runoff is usually formed by seasonal snow melting and may be expressed as the spring flood depth of runoff $(h, \mathrm{~mm} /$ (time period)), which is the volume of spring flood runoff $\left(\mathrm{m}^{3}\right)$ from a drainage basin divided by its area $\left(\mathrm{m}^{2}\right)$. The spring flood depth of runoff was chosen instead of the maximal discharge because this allows for mapping the spatial distribution of maximal runoff. Thus, the spring flood depth of runoff can be used to define regions for which the design maximal discharges should be corrected according to climate change scenarios. After such regions were delineated, the correction of the maximal discharge with the required probability of exceedance can be done using climate projections. From the spring flood depth of runoff, the river discharge with a required exceedance probability $\left(Q_{\mathrm{p}}, \mathrm{m}^{3} \mathrm{~s}^{-1}\right)$ is calculated according to the method proposed in Guideline SP33-1012003 (2004):

$Q_{\mathrm{p}}=k_{0} \mu h_{\mathrm{p}} \delta \delta_{1} \delta_{2} F /(F+b)^{n}$,

where $k_{0}$ is the flood coincidence factor, which reflects a simultaneousness of precipitation/melting water input, i.e. depends on the shape of the hydrograph; $\mu$ is the factor of inequality of the depth of runoff and maximal discharge statistics; $h_{\mathrm{p}}$ is the spring flood depth of runoff ( $\mathrm{mm}$; time period) with chosen probability $p(0.1,0.05,0.01)$ estimated from the exceedance probability curve (or PDF); $\delta, \delta_{1}, \delta_{2}$ are the watershed fractions for lake, forest, and swamp respectively; $F$ is the watershed area $\left(\mathrm{km}^{2}\right) ; b$ is the additional area that adjusts for the reduction of runoff $\left(\mathrm{km}^{2}\right)$; and $n$ is the degree of runoff reduction. For the ungauged basin the value $k_{0}$ is estimated from observations on a neighbouring gauge located on the same type of landscape (Guideline SP33-101$2003,2004)$. In our study, the value $k_{0}$ was considered to be constant for the reference and projected periods. The values of $\mu, \delta, \delta_{1}, \delta_{2}, b$, and $n$ may be obtained from lookup tables (Guideline SP33-101-2003, 2004) or from global datasets representing land cover (e.g. Bartholomé and Belward, 2005).

\subsection{Model}

The core of the probabilistic hydrological model is a linear differential equation with stochastic components having solutions statistically equivalent to the solutions of the FokkerPlanck-Kolmogorov (FPK) equation (Pugachev et al., 1974). It allows the evaluation of the probability density function of a random hydrological variable with parameters dependent on climate variables. Under a quasi-stationary assumption of climate change, the FPK equation is approximated by a system of algebraic equations to simulate initial statistical moments of multi-year runoff (Kovalenko, 1993, 2014) (see Appendix for details). These moments are further used to calculate the PDF parameters and to model them using the theoretical formulations (e.g. Pearson type III). In our study, the simple model suggested in Kovalenko et al. (2010) was used to model the statistical moments of the spring flood depth of runoff:

$-\bar{c} m_{1}+\bar{N}=0$,

$-2 \bar{c} m_{2}+2 \bar{N} m_{1}+G_{\widetilde{N}}=0$,

where $m_{1}(\mathrm{~mm})$ and $m_{2}\left(\mathrm{~mm}^{2}\right)$ are the first and second initial statistical moments of the flood spring depth of runoff for a period of 20-30 years; $\bar{c}=1 / k \tau$ is the inverse of the runoff coefficient $k$ (which is a dimensionless coefficient, the ratio of the amount of runoff to the amount of precipitation received) times the watershed reaction delay $(\tau) ; \bar{N}(\mathrm{~mm})$ is the mean value of annual precipitation for a period of 20 30 years. The parameter $G_{\widetilde{N}}\left(\mathrm{~mm}^{2}\right)$ reflects the variance in annual precipitation.

The system of Eq. (2) allows for evaluating the multi-year runoff statistical moments for the projected time period based on the climatology and multi-year runoff statistics for the reference (historical) period. The climate and runoff regime are steady within both the reference and projected periods (the assumption of quasi-stationarity). The "steady" aspect is defined statistically; i.e. there are no significant trends and changes in the mean values of the meteorological and hydrological characteristics within the periods. However, the basic statistics (mean, CV, and coefficient of skewness - CS - values) are significantly different for the reference and projected periods.

The system of Eq. (2) was applied as follows:

i. The initial statistical moments from the observed hydrological and meteorological time series for the chosen reference $(r)$ period $\left(m_{1 \mathrm{r}}, m_{2 \mathrm{r}}\right.$ and $\left.\bar{N}_{\mathrm{r}}\right)$ were estimated.

ii. The model parameters for the reference period were assessed:

$\bar{c}_{\mathrm{r}}=\bar{N} / m_{1 \mathrm{r}}, G_{\widetilde{N}_{\mathrm{r}}}=2\left(\bar{c}_{\mathrm{r}} m_{2 \mathrm{r}}-\bar{N}_{\mathrm{r}} m_{1 \mathrm{r}}\right)$.

iii. The future $(f)$ values of two statistical moments $\left(m_{1 \mathrm{f}}\right.$ and $m_{2 \mathrm{f}}$ ) from the projected mean of the annual precipitation $\bar{N}_{\mathrm{f}}$ were calculated, provided that the future 
parameter values $\left(\bar{c}_{\mathrm{f}}\right.$ and $\left.G_{\widetilde{N} \mathrm{f}}\right)$ are known:

$m_{1 \mathrm{f}}=\bar{N}_{\mathrm{f}} / \bar{c}_{\mathrm{f}}$,

$m_{2 \mathrm{f}}=\left(2 \bar{N}_{\mathrm{f}} m_{1 \mathrm{f}}+G_{\tilde{N} \mathrm{f}}\right) / 2 \bar{c}_{\mathrm{f}}$.

The parameter $\bar{c}$ was set either as constant for the projected time period (as proposed by Kovalenko et al., 2010), or dependent on the average precipitation and air temperature as suggested by Shevnina (2012). In our study, the parameter $G_{\tilde{N}}$ was considered to be constant for the projected time period.

iv. The future mean value and CV were obtained. The future CS was calculated from the given ratio of $\mathrm{CS} / \mathrm{CV}$, which was considered to be constant for the reference and future periods. The future PDFs were constructed (with Pearson type III theoretical distribution) and used to estimate the spring flood flow depth of runoff with the required exceedance probability. Then, the peak discharges were calculated using Eq. (1).

\subsection{Validation}

Rainfall-runoff models are usually validated against observed time series (Lehner et al., 2006; Arheimer and Lindström, 2015). The system of Eq. (2) allows for simulating the PDF parameters for the multi-year runoff without producing time series. The predicted PDF parameters for the single time period are based on the PDF parameters calculated for the other period. Two time periods should have different parameter values and the difference should be statistically significant (Kovalenko et al., 2010). Such kinds of periods were found in the observed time series, enabling us to perform the probabilistic model validation using a cross-validation procedure. In the simplest cross-validation procedure, the observational dataset is separated into two sub-sets, called the training set and the testing/control set. From the training set the model parameters are evaluated and then used to nominally predict the parameters of the control PDFs (Kovalenko, 1993). In our case, the nominally predicted PDF was compared with the empirical distribution for the testing/control period using the Pearson $\chi$-squared and Kolmogorov-Smirnov onesample tests.

The whole period of observations was divided into the subperiods with the statistically significant difference (shift) in the mean values. Dividing into the subsamples was done according to the Student's $t$ test using the moving window approach (Ducré-Robitaille et al., 2003). We begin from setting the size of the first subsample to the chosen minimum (15 members). The size of the second subsample in this case is the size of the total sample $(N)$ minus the chosen minimum ([N-15] in Fig. 2). Between these two subsamples we calculate the value of the $t$ test. Then, the size of the first subsample was incremented by the iterator $i=1,2,3$, etc. until the size of the second subsample is equal to the chosen minimum. The values of $t$ test were calculated for each step and

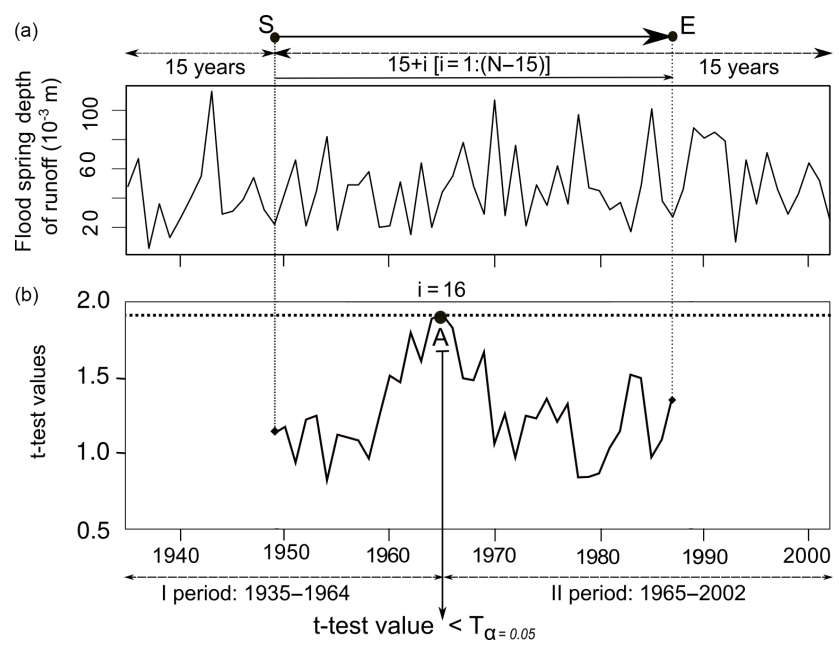

Figure 2. The partition of the observed time series of the spring flood depth of runoff (a) into sub-periods with a statistically significant shift in the mean value by the $t$ test (b) for the Yana River at the Verkhoyansk gauge: $T_{\alpha=0.05}$ is the critical value of the $t$ test at the threshold of statistical significance equal to 0.05 (dotted line on the bottom). See the text for the explanation of $A, S, E, N$, and $i$.

were linked to the years of the time series subdivision. Finally, the whole time series was divided by the year with the $t$ test exceeding the critical value of $p<0.05$ level of statistical significance. The Student's test critical values accounting for the asymmetry and autocorrelation in hydrological time series were used (Rogdestvenskiy and Saharyuk, 1981). If several partitioning years were found, we gave preference to the year that divided the time series into two approximately equal sub-periods.

The initial first and second statistical moments of the flood spring depth of runoff for each sub-period were calculated according to Bowman and Shenton (1998). The third moment was estimated from the entire time series, and the ratio of CS / CV was calculated. Then, the mean values of the annual precipitation and air temperature for each sub-period were also calculated. The resulting dataset included pairs of statistical moments for the spring flood depth of runoff $\left(m_{1}^{\mathrm{I}}\right.$, $\left.m_{1}^{\mathrm{II}}, m_{2}^{\mathrm{I}}, m_{2}^{\mathrm{II}}\right)$, the mean values of air temperature $\left(\bar{T}^{\mathrm{I}}, \bar{T}^{\mathrm{II}}\right)$, and annual precipitation $\left(\bar{N}^{\mathrm{I}}, \bar{N}^{\mathrm{II}}\right)$.

For the cross-validation, we (i) considered the first subperiod as the training and calculated the reference values of the model parameters, and (ii) predicted nominally ("in the past") the first and second moments for the second subperiod (which was considered as a control). The same procedure was applied backwards. We validated two versions of the model: (i) with the basic parameters setting as proposed by Kovalenko et al. (2010) and (ii) with the regional-oriented parameterization as suggested by Shevnina (2012). The empirical and nominally predicted PDFs were compared for each sub-period and the goodness-of-fit between them was estimated using the Pearson $\chi$-squared and Kolmogorov- 
(a)

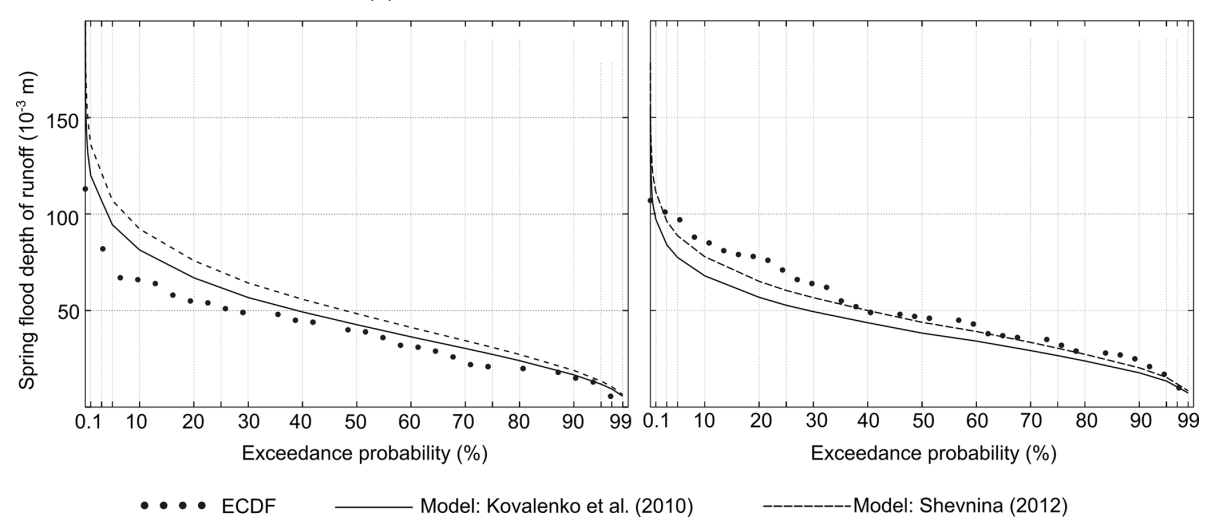

Figure 3. The nominally predicted exceedance probability curves compared with the empirical exceedance probability (ECDF) for the sub-periods with statistically significant shift in the mean value for the Yana River at Verkhoyansk: (a) the period 1935-1964; (b) the period 1965-2002.

Smirnov one-sample tests. If the value of the test did not exceed the critical value of $p<0.05$ level of statistical significance, the nominal prediction of PDF was considered to be successful. The model prediction scores were obtained as a percentage of the matching PDFs for the whole dataset.

The model cross-validation was performed with observations collected during the period from the 1930s to the 2000s. The observed data were extracted from the official edition of the multi-year/year books of the State Water Cadastre of the Russian Federation (see e.g. Kuznetsov, 1966). The spring flood depth of runoff time series at 76 gauges for medium size catchments $\left(1000-50000 \mathrm{~km}^{2}\right)$ were used. The gauges are located on the territory of the Russian Arctic. The gauging sites are irregularly distributed over the territory with $65 \%$ of the points located in the western part of the Arctic. The time series lengths vary from 26 to 77 years with an average of 51 years. The dataset has no gaps in the time series of $66 \%$ of the considered gauges. The time series for $18 \%$ of the gauges have missing values for more than $5 \%$ of their length.

The example of the cross-validation for the Yana River at Verkhoyansk gauge is shown in Fig. 2. In partitioning the time series into two sub-periods, the time series (Fig. 2, top panel) was first divided at the point $S=1949$ and the $t$ test value was calculated. Then the $t$ test values were calculated step-by-step until the point $E=1987$ with increments of 1 year. At the point $A=1965$ (Fig. 2, bottom panel), the $t$ test exceeds the critical value at $p<0.05$ level of statistical significance. Thus, two periods were differentiated: the first sub-period, covering the interval 1935-1964 with $m_{1}^{\mathrm{I}}=41.2(\mathrm{~mm})$ and the second sub-period covering the interval 1965-2002 with $m_{1}^{\mathrm{II}}=52.3(\mathrm{~mm})$. The second statistical moments $\left(m_{2}^{\mathrm{I}}, m_{2}^{\mathrm{II}}\right)$ of each period were calculated as well. Then, the average values of the annual precipitation $\left(\bar{N}^{\mathrm{I}}, \bar{N}^{\mathrm{II}}\right)$ and the annual-mean air temperature $\left(\bar{T}^{\mathrm{I}}, \bar{T}^{\mathrm{II}}\right)$ were also calculated for the two sub-periods. The reference values for the parameters $\left(\bar{c}_{\mathrm{r}}, G_{\tilde{N}_{\mathrm{r}}}\right)$ were estimated using $m_{1 \mathrm{r}}^{\mathrm{I}}, m_{2 \mathrm{r}}^{\mathrm{I}}$, and $\bar{N}_{\mathrm{r}}^{\mathrm{I}}$ for the sub-period 1935-1964 (considered as the training). Then, the nominally predicted or modelled $m_{1 \mathrm{f}}^{\mathrm{II}}, m_{2 \mathrm{f}}^{\mathrm{II}}$ were calculated from $\bar{N}_{\mathrm{f}}^{\mathrm{II}}$ for the sub-period 19652002 (considered as the control). Finally, the nominally predicted mean value and $\mathrm{CV}$ were calculated from the simulated runoff statistics and CS was estimated from the ratio of CS / CV for each period. These values were used to predict nominal PDF (or the exceedance probability curve Fig. 3) with the Pearson type III distribution. Then, the nominally predicted and empirical PDF were compared (Fig. 3). The same procedure was then done backwards: the subperiod 1965-2002 was considered as the training and the statistical moments were nominally predicted for the sub-period 1935-1964 (considered as the control in this case).

The sub-periods with a statistically significant shift in the mean values for the spring flood depth of runoff were selected for the 23 time series (Table 1), which constitutes $30 \%$ of the data considered. For the corresponding watersheds, the average values of the annual precipitation and the mean air temperature were calculated using observations from 37 meteorological stations (approximately two stations per watershed) for each sub-period (Table 1). The observed meteorological time series were obtained from Razuvaev et al. (1993), Radionov and Fetterer (2003), N. Bryazgin (personal communication, 2008) and the multi-year catalogs on climatology (e.g. Catalogue of Climatology of USSR, 1989).

For each gauge and sub-period, the statistical moments were nominally predicted using Eq. (4) for the two versions of the model parameter settings (Table 2). We also compared these predictions with the case where the nominally predicted PDF for one sub-period was modelled using the statistical values calculated from the observed data of the other sub-period ("no model" case). The "no model" case illustrates the "stationary climate" scenario in which climate 
Table 1. Sub-periods with the statistically significant shift in the mean values of the spring flood depth of runoff with the multi-year statistics and climatology.

\begin{tabular}{|c|c|c|c|c|c|c|c|c|c|}
\hline $\begin{array}{l}\text { Gauge } \\
\text { ID }\end{array}$ & River & $\begin{array}{r}\text { Catchment } \\
\text { area } \\
{\left[\mathrm{km}^{2}\right]}\end{array}$ & Period & $\begin{array}{r}m_{1} \\
{[\mathrm{~mm}]}\end{array}$ & $\begin{array}{r}m_{2} \\
{\left[\mathrm{~mm}^{2}\right]}\end{array}$ & $\mathrm{CV}$ & $\begin{array}{l}\mathrm{CS} / \\
\mathrm{CV}\end{array}$ & $\begin{array}{c}\bar{N} \\
{[\mathrm{~mm}]}\end{array}$ & $\begin{array}{r}\bar{T} \\
{\left[{ }^{\circ} \mathrm{C}\right]}\end{array}$ \\
\hline 01176 & Bohapcha & 13600 & $\begin{array}{l}1934-1949 \\
1950-1980\end{array}$ & $\begin{array}{l}111 \\
141\end{array}$ & $\begin{array}{l}15401 \\
23907\end{array}$ & $\begin{array}{l}0.50 \\
0.45\end{array}$ & $\begin{array}{l}2.5 \\
2.8\end{array}$ & $\begin{array}{l}421 \\
435\end{array}$ & $\begin{array}{l}-12.1 \\
-12.4\end{array}$ \\
\hline 01309 & Seimchan & 2920 & $\begin{array}{l}1941-1956 \\
1957-1977\end{array}$ & $\begin{array}{l}190 \\
157\end{array}$ & $\begin{array}{l}40779 \\
25842\end{array}$ & $\begin{array}{l}0.36 \\
0.22\end{array}$ & $\begin{array}{l}3.1 \\
5.1\end{array}$ & $\begin{array}{l}373 \\
305\end{array}$ & $\begin{array}{l}-11.5 \\
-11.4\end{array}$ \\
\hline 01623 & Srednekan & 1730 & $\begin{array}{l}1935-1950 \\
1951-1980\end{array}$ & $\begin{array}{l}148 \\
180\end{array}$ & $\begin{array}{l}25067 \\
36145\end{array}$ & $\begin{array}{l}0.38 \\
0.34\end{array}$ & $\begin{array}{l}4.0 \\
4.5\end{array}$ & $\begin{array}{l}426 \\
431\end{array}$ & $\begin{array}{l}-10.7 \\
-11.1\end{array}$ \\
\hline 03403 & Malaya Kuonapka & 2030 & $\begin{array}{l}1943-1985 \\
1986-2002\end{array}$ & $\begin{array}{r}97.5 \\
116\end{array}$ & $\begin{array}{l}10848 \\
14297\end{array}$ & $\begin{array}{l}0.36 \\
0.25\end{array}$ & $\begin{array}{l}0.8 \\
1.1\end{array}$ & $\begin{array}{l}255 \\
262\end{array}$ & $\begin{array}{l}-13.8 \\
-13.1\end{array}$ \\
\hline 03414 & Yana & 45300 & $\begin{array}{l}1935-1964 \\
1965-2002\end{array}$ & $\begin{array}{l}41.1 \\
52.1\end{array}$ & $\begin{array}{l}2190 \\
3456\end{array}$ & $\begin{array}{l}0.55 \\
0.48\end{array}$ & $\begin{array}{l}1.2 \\
1.4\end{array}$ & $\begin{array}{l}177 \\
178\end{array}$ & $\begin{array}{l}-14.8 \\
-14.6\end{array}$ \\
\hline 03518 & Nera & 2230 & $\begin{array}{l}1944-1985 \\
1986-2002\end{array}$ & $\begin{array}{l}67.0 \\
84.6\end{array}$ & $\begin{array}{l}5439 \\
8214\end{array}$ & $\begin{array}{l}0.46 \\
0.37\end{array}$ & $\begin{array}{l}0.8 \\
1.0\end{array}$ & $\begin{array}{l}227 \\
222\end{array}$ & $\begin{array}{l}-15.8 \\
-14.4\end{array}$ \\
\hline 09425 & Turukhan & 10100 & $\begin{array}{l}1941-1970 \\
1971-1999\end{array}$ & $\begin{array}{l}232 \\
260\end{array}$ & $\begin{array}{l}56198 \\
70304\end{array}$ & $\begin{array}{l}0.21 \\
0.20\end{array}$ & $\begin{array}{l}1.3 \\
1.4\end{array}$ & $\begin{array}{l}491 \\
494\end{array}$ & $\begin{array}{l}-7.4 \\
-7.4\end{array}$ \\
\hline 11574 & Pyakupur & 31400 & $\begin{array}{l}1954-1970 \\
1971-2001\end{array}$ & $\begin{array}{l}142 \\
162\end{array}$ & $\begin{array}{l}21140 \\
27884\end{array}$ & $\begin{array}{l}0.22 \\
0.23\end{array}$ & $\begin{array}{l}4.2 \\
3.7\end{array}$ & $\begin{array}{l}482 \\
514\end{array}$ & $\begin{array}{l}-6.4 \\
-6.0\end{array}$ \\
\hline 11805 & Nadym & 48000 & $\begin{array}{l}1955-1974 \\
1975-1991\end{array}$ & $\begin{array}{l}162 \\
140\end{array}$ & $\begin{array}{l}27632 \\
21607\end{array}$ & $\begin{array}{l}0.23 \\
0.32\end{array}$ & $\begin{array}{l}3.0 \\
2.2\end{array}$ & $\begin{array}{l}490 \\
471\end{array}$ & $\begin{array}{l}-6.4 \\
-5.0\end{array}$ \\
\hline 70047 & Solza & 1190 & $\begin{array}{l}1928-1958 \\
1959-1980\end{array}$ & $\begin{array}{l}190 \\
155\end{array}$ & $\begin{array}{l}38356 \\
26046\end{array}$ & $\begin{array}{l}0.25 \\
0.29\end{array}$ & $\begin{array}{l}0.9 \\
0.8\end{array}$ & $\begin{array}{l}525 \\
552\end{array}$ & $\begin{array}{l}1.3 \\
1.0\end{array}$ \\
\hline 70153 & Yug & 15200 & $\begin{array}{l}1931-1946 \\
1947-1980\end{array}$ & $\begin{array}{l}126 \\
144\end{array}$ & $\begin{array}{l}16716 \\
22994\end{array}$ & $\begin{array}{l}0.23 \\
0.33\end{array}$ & $\begin{array}{l}2.0 \\
1.4\end{array}$ & $\begin{array}{l}575 \\
591\end{array}$ & $\begin{array}{l}1.6 \\
1.6\end{array}$ \\
\hline 70180 & Vychegda & 26500 & $\begin{array}{l}1930-1956 \\
1957-1980\end{array}$ & $\begin{array}{l}147 \\
167\end{array}$ & $\begin{array}{l}22960 \\
29632\end{array}$ & $\begin{array}{l}0.25 \\
0.25\end{array}$ & $\begin{array}{l}0.0 \\
0.0\end{array}$ & $\begin{array}{l}491 \\
550\end{array}$ & $\begin{array}{l}-0.1 \\
-0.5\end{array}$ \\
\hline 70360 & Lodma & 1400 & $\begin{array}{l}1939-1958 \\
1959-1977\end{array}$ & $\begin{array}{l}219 \\
174\end{array}$ & $\begin{array}{l}53184 \\
32650\end{array}$ & $\begin{array}{l}0.33 \\
0.28\end{array}$ & $\begin{array}{l}1.2 \\
1.4\end{array}$ & $\begin{array}{l}533 \\
546\end{array}$ & $\begin{array}{l}0.7 \\
0.7\end{array}$ \\
\hline 70366 & Kuloy & 3040 & $\begin{array}{l}1927-1958 \\
1959-1980\end{array}$ & $\begin{array}{l}134 \\
110\end{array}$ & $\begin{array}{l}20549 \\
13582\end{array}$ & $\begin{array}{l}0.38 \\
0.35\end{array}$ & $\begin{array}{l}1.4 \\
1.5\end{array}$ & $\begin{array}{l}467 \\
446\end{array}$ & $\begin{array}{l}1.0 \\
0.6\end{array}$ \\
\hline 70410 & Pechora & 9620 & $\begin{array}{l}1914-1930 \\
1931-1993\end{array}$ & $\begin{array}{l}302 \\
276\end{array}$ & $\begin{array}{l}94159 \\
79535\end{array}$ & $\begin{array}{l}0.18 \\
0.21\end{array}$ & $\begin{array}{l}-0.4 \\
-0.3\end{array}$ & $\begin{array}{l}516 \\
564\end{array}$ & $\begin{array}{l}-1.0 \\
-1.0\end{array}$ \\
\hline 70414 & Pechora & 29400 & $\begin{array}{l}1938-1956 \\
1957-1980\end{array}$ & $\begin{array}{l}250 \\
278\end{array}$ & $\begin{array}{l}65806 \\
79262\end{array}$ & $\begin{array}{l}0.23 \\
0.16\end{array}$ & $\begin{array}{l}0.5 \\
0.8\end{array}$ & $\begin{array}{l}490 \\
601\end{array}$ & $\begin{array}{l}-1.0 \\
-1.3\end{array}$ \\
\hline 70466 & Usa & 2750 & $\begin{array}{l}1936-1957 \\
1958-1980\end{array}$ & $\begin{array}{l}385 \\
424\end{array}$ & $\begin{array}{l}155399 \\
185601\end{array}$ & $\begin{array}{l}0.22 \\
0.18\end{array}$ & $\begin{array}{l}1.5 \\
1.8\end{array}$ & $\begin{array}{l}483 \\
558\end{array}$ & $\begin{array}{l}-4.3 \\
-5.3\end{array}$ \\
\hline 70509 & Izhma & 15000 & $\begin{array}{l}1933-1949 \\
1950-1980\end{array}$ & $\begin{array}{l}189 \\
160\end{array}$ & $\begin{array}{l}37779 \\
26839\end{array}$ & $\begin{array}{l}0.24 \\
0.22\end{array}$ & $\begin{array}{l}0.1 \\
0.1\end{array}$ & $\begin{array}{l}465 \\
534\end{array}$ & $\begin{array}{l}-0.5 \\
-0.9\end{array}$ \\
\hline 70522 & Ukhta & 4290 & $\begin{array}{l}1934-1949 \\
1950-1980\end{array}$ & $\begin{array}{l}170 \\
144\end{array}$ & $\begin{array}{l}30706 \\
22032\end{array}$ & $\begin{array}{l}0.25 \\
0.25\end{array}$ & $\begin{array}{l}0.9 \\
0.9\end{array}$ & $\begin{array}{l}473 \\
535\end{array}$ & $\begin{array}{l}-0.5 \\
-0.5\end{array}$ \\
\hline 70531 & Pizhma & 4890 & $\begin{array}{l}1937-1964 \\
1965-1980\end{array}$ & $\begin{array}{l}129 \\
150\end{array}$ & $\begin{array}{l}18041 \\
24264\end{array}$ & $\begin{array}{l}0.29 \\
0.28\end{array}$ & $\begin{array}{l}0.9 \\
0.9\end{array}$ & $\begin{array}{l}486 \\
552\end{array}$ & $\begin{array}{l}-1.7 \\
-2.3\end{array}$ \\
\hline
\end{tabular}


Table 1. Continued.

\begin{tabular}{|c|c|c|c|c|c|c|c|c|c|}
\hline $\begin{array}{l}\text { Gauge } \\
\text { ID }\end{array}$ & River & $\begin{array}{r}\text { Catchment } \\
\text { area } \\
{\left[\mathrm{km}^{2}\right]}\end{array}$ & Period & $\begin{array}{r}m_{1} \\
{[\mathrm{~mm}]}\end{array}$ & $\begin{array}{r}m_{2} \\
{\left[\mathrm{~mm}^{2}\right]}\end{array}$ & $\mathrm{CV}$ & $\begin{array}{l}\mathrm{CS} / \\
\mathrm{CV}\end{array}$ & $\begin{array}{c}\bar{N} \\
{[\mathrm{~mm}]}\end{array}$ & $\begin{array}{r}\bar{T} \\
{\left[{ }^{\circ} \mathrm{C}\right]}\end{array}$ \\
\hline 71104 & Kola & 3780 & $\begin{array}{l}1928-1958 \\
1959-1994\end{array}$ & $\begin{array}{l}182 \\
203\end{array}$ & $\begin{array}{l}35539 \\
43785\end{array}$ & $\begin{array}{l}0.27 \\
0.25\end{array}$ & $\begin{array}{l}2.6 \\
2.6\end{array}$ & $\begin{array}{l}350 \\
459\end{array}$ & $\begin{array}{l}0.5 \\
0.1\end{array}$ \\
\hline 71199 & Umba & 6920 & $\begin{array}{l}1931-1958 \\
1959-1994\end{array}$ & $\begin{array}{l}180 \\
149\end{array}$ & $\begin{array}{l}34762 \\
23942\end{array}$ & $\begin{array}{l}0.27 \\
0.28\end{array}$ & $\begin{array}{l}0.6 \\
0.6\end{array}$ & $\begin{array}{l}414 \\
475\end{array}$ & $\begin{array}{l}-1.1 \\
-1.6\end{array}$ \\
\hline 71241 & Yena & 1600 & $\begin{array}{l}1934-1948 \\
1949-1980\end{array}$ & $\begin{array}{l}100 \\
129\end{array}$ & $\begin{array}{r}10625 \\
18041\end{array}$ & $\begin{array}{l}0.25 \\
0.29\end{array}$ & $\begin{array}{l}0.7 \\
0.7\end{array}$ & $\begin{array}{l}451 \\
557\end{array}$ & $\begin{array}{r}0.2 \\
-0.3\end{array}$ \\
\hline
\end{tabular}

Notations: $m_{1}$ and $m_{2}$ are the initial first and second statistical moments of the spring flood depth of runoff; CV is the coefficient of variation; CS is the coefficient of skewness; $\bar{N}$ is the mean of annual precipitation; $\bar{T}$ is the mean of annual air temperature.

change is not taken into account, and thus the PDFs' parameters are not modified for the period of nominal prediction. This case reflects the situation as considered in the guidelines for engineering hydrology (Guideline SP33-1012003, 2004; Bulletin 17-B, 1982), when only the observed runoff time series were used to evaluate the PDF parameters. The percentage of nominally predicted PDFs that matched successfully to the empirical PDFs according to the Pearson $\chi$-squared and Kolmogorov-Smirnov one-sample tests were evaluated for each version of the model parameterization. Table 3 provides the percentages of successful coincidences for the PDFs, which were obtained from the available cross-validation dataset (46 pairs of simulation and empirical PDFs).

The model with the constant parameters gives a more conforming result than the "no model" case: the percentage of successfully matched PDFs is 5-10 percentage points higher. Using the regional parameterization algorithm to calculate the parameter $\bar{c}$ gives an even more reliable result, with the values 11-22 percentage points higher. Hereinafter, we used the regional-oriented parameterization scheme to estimate the future PDF parameters of the flood spring depth of runoff based on the climate change projections.

\subsection{Data and method application}

In performing the long-term assessment of the extreme flood events in the Russian Arctic, the period from 1930 to 1980 was chosen as the reference period, while the projected period was from 2010 to 2039. The following datasets were used: (i) the climatology for the reference period (Fig. 4a and b), (ii) the mean values and CVs of the spring flood depth of runoff for the reference period (Fig. $4 \mathrm{c}$ and d), and (iii) the climatology for the projected period (Fig. 4e and f). The reference climatology was obtained from the climatology catalogs and the archives of the Arctic and Antarctic Research Institute, covering 209 meteorological stations (Radionov and Fetterer, 2003; Catalogue of Climatology of USSR, 1989). The climatology was interpolated into the model grid nodes using the algorithm by Hofierka et al. (2002). For the precipitation, we use annual values, although the spring floods are formed only by snow cover and spring rainfall. However, in the Arctic the relationship between spring flood depth of runoff and both annual and winter-spring sums of precipitation are strong (Shevnina, 2011).

The climatology for the projected period is provided by the climate models (Pachauri and Reisinger, 2007; Taylor et al., 2012). In this study, the projections of two emissions scenarios (SRES: A1B and B1) and two representative concentration pathways (RCPs: 2.6 and 4.5) scenarios were extracted from CMIP3 and CMIP5 datasets. Results of climate models of the Max Planck Institute for Meteorology MPIM:ECHAM5 (Roeckner et al., 2003), the Max Planck Institute Earth System Model MPI-ESM (Giorgetta et al., 2013), the Hadley Center for Climate Prediction and Research HadCM3 (Johns et al., 2003), HadGEM2-A (Collins et al., 2008), the Geophysical Fluid Dynamics Laboratory GFDL:CM2 (Delworth et al., 2006), and the Canadian Center for Climate Modelling Earth System Model CanESM2 (von Salzen et al., 2013) were used. These global climate models (GCMs) produce approximately similar climate projections. This allows one to testify that the hydrological modelling results do not vary much under slightly different climate forcing factors. To obtain the climate forcing, the projected mean values of air temperature and precipitation were corrected using the delta changes method (Fowler et al., 2007). For that, the relative changes in the variables (in degrees for the temperature and in $\%$ for precipitation) were first calculated based on the historical simulations and observed climatology for the reference period. Then these changes were added to/multiplied to the projected climatology. The corrected mean values of the annual precipitation and annual average air temperature were estimated for the nodes of the corresponding climate model grids.

The means and CVs of the spring flood depth of runoff were extracted from the maps of Rogdestvenskiy (1986) and Vodogretskiy (1986) by scanning the paper maps, image georeferencing, digitizing the data, and interpolating onto the 


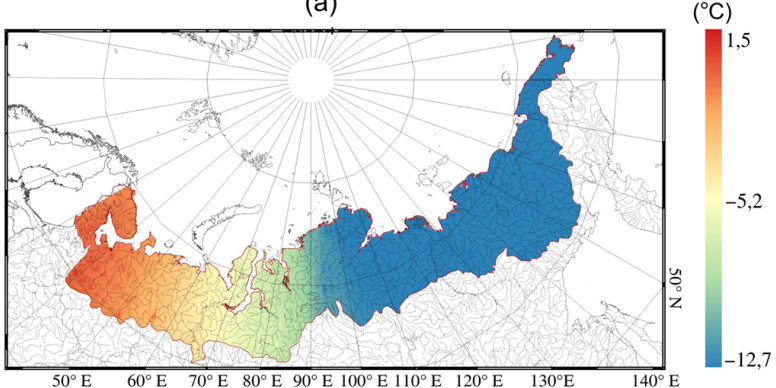

(c)

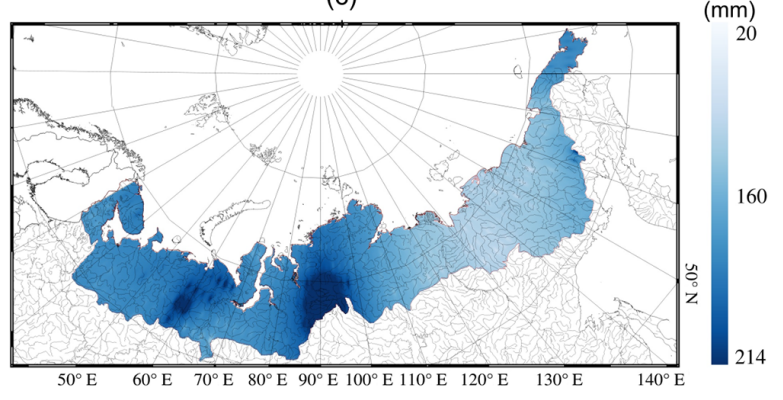

(e)

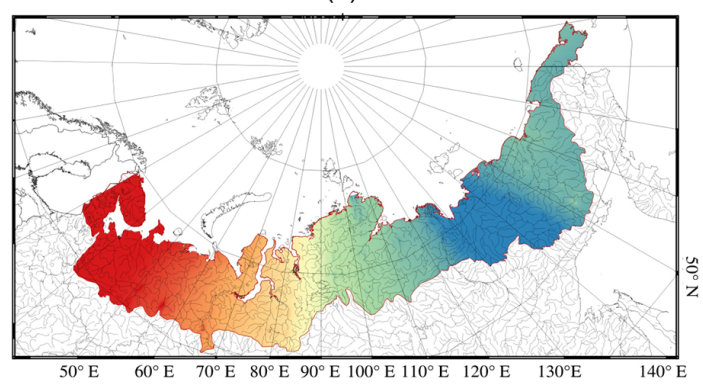

$\left({ }^{\circ} \mathrm{C}\right)$

$(\mathrm{mm})$

160

$\left({ }^{\circ} \mathrm{C}\right)$

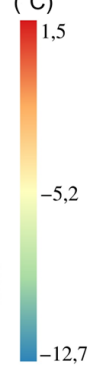

(b)

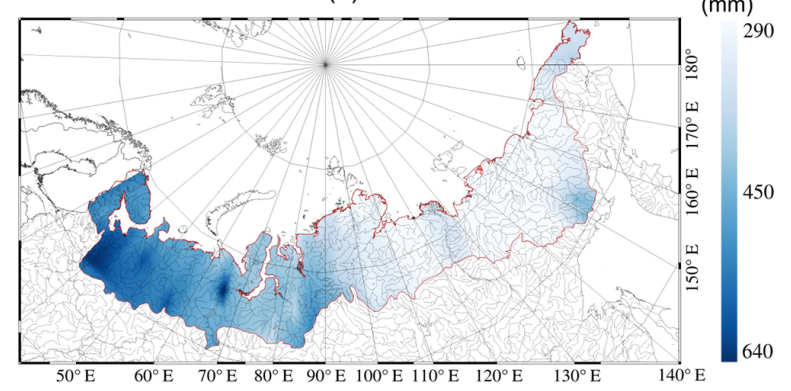

(d)

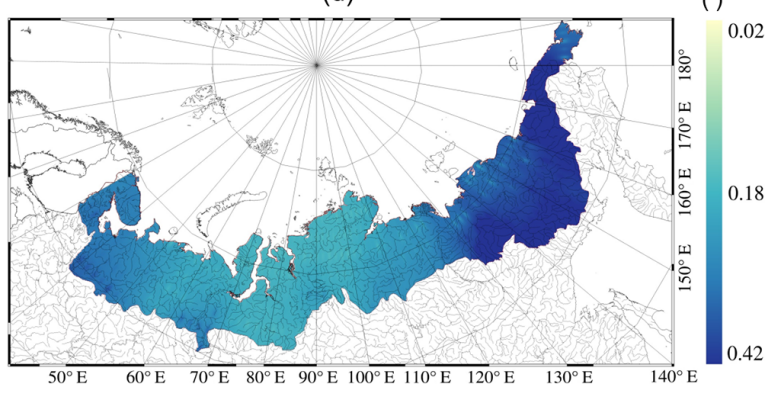

(f)

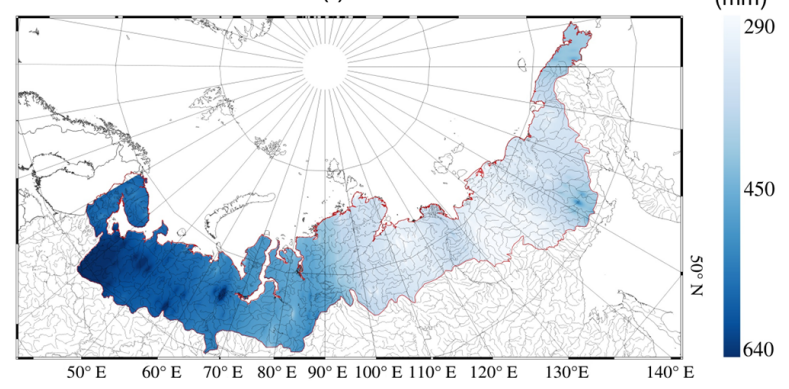

Figure 4. The data used in the study: (a) the mean values of annual air temperature for the reference period (Radionov and Fetterer, 2003; Catalogue of Climatology of USSR, 1989); (b) the mean values of the annual precipitation for the reference period (Radionov and Fetterer, 2003; Catalogue of Climatology of USSR, 1989); (c) the mean values of the spring flood depth of runoff for the reference period (Vodogretskiy, 1986); (d) the coefficients of variation of the spring flood depth of runoff for the reference period (Rogdestvenskiy, 1986); (e) the mean values of the annual air temperature for the projected period (2010-2039) under the RCP4.5, average of four GCMs (Taylor et al., 2012); (f) the mean values of the annual precipitation for the projected period (2010-2039) under the RCP4.5, average of four GCMs (Taylor et al., 2012). The territory of the Russian Arctic is outlined according to Ivanov and Yankina (1991).

grid nodes of the particular GCM. These maps were designed based on the observations for the period from the early 1930s up to 1980 (Rogdestvenskiy, 1988). In producing these maps, the observations on catchments of medium size (from 1000 to $50000 \mathrm{~km}^{2}$ ) located within the single climate zone were used. Thus, the features of runoff processes on the local scale (appearing on small watersheds) and the global scale (revealed on huge watersheds located within several climate zones) as well as floods due to ice jams and tides/surges were not considered. In our study, no time series of multiyear runoff were used to evaluate the mean value and $\mathrm{CV}$ for the reference period and no extrapolation was applied for the regions without observations.

The values of $\bar{c}$ and $G_{\tilde{N}}$ were calculated using Eq. (3) for each node of the particular climate model grid. Then, the fu- ture first and the second initial statistical moments were calculated according to Eq. (4) using the projected climatology, and the future values of $\mathrm{CVs}$ of the spring flood depth of runoff were evaluated. The future values of $\mathrm{CS}$ were estimated using the regional ration of CS / CV with the assumption that it is constant for the reference and projected period. The maximum discharge with the required exceedance probability was calculated according to Eq. (1) (see Sect. 3 for the example). Our study was performed for the period 20102039, since within this interval the existing and developing socio-economic infrastructure (bridges, oil/gas pipelines, roads, and dams) will operate. 
Table 2. The model parameters and the nominally predicted multi-year statistics of the spring flood depth of runoff for the catchments selected for the cross-validation.

\begin{tabular}{|c|c|c|c|c|c|c|c|c|}
\hline $\begin{array}{l}\text { Gauge } \\
\text { ID }\end{array}$ & Lat/long & Period & $\begin{array}{r}G_{\widetilde{N} \mathrm{f}} \\
{\left[\mathrm{mm}^{2}\right]}\end{array}$ & $\bar{c}_{\mathrm{f}}$ & $\begin{array}{r}m_{1 \mathrm{f}} \\
{[\mathrm{mm}]}\end{array}$ & $\begin{array}{r}m_{2 \mathrm{f}} \\
{\left[\mathrm{mm}^{2}\right]}\end{array}$ & $\mathrm{CV}_{\mathrm{f}}$ & $\mathrm{CS}_{\mathrm{f}}$ \\
\hline \multirow[t]{2}{*}{01176} & $62^{\circ} 06^{\prime} \mathrm{N}$ & 1934-1949 & 23366 & 3.79 & 115 & 16234 & 0.48 & 1.20 \\
\hline & $150^{\circ} 37^{\prime} \mathrm{E}$ & 1950-1980 & 24841 & 3.09 & 136 & 22647 & 0.46 & 1.28 \\
\hline \multirow[t]{2}{*}{01309} & $63^{\circ} 17^{\prime} \mathrm{N}$ & 1941-1956 & 18370 & 1.96 & 155 & 28815 & 0.44 & 1.38 \\
\hline & $152^{\circ} 02^{\prime} \mathrm{E}$ & 1957-1977 & 4635 & 1.94 & 141 & 20941 & 0.25 & 1.26 \\
\hline \multirow[t]{2}{*}{01623} & $62^{\circ} 22^{\prime} \mathrm{N}$ & 1935-1950 & 18208 & 2.88 & 150 & 25584 & 0.38 & 1.50 \\
\hline & $152^{\circ} 20^{\prime} \mathrm{E}$ & 1951-1980 & 17936 & 2.39 & 178 & 35398 & 0.34 & 1.54 \\
\hline \multirow[t]{2}{*}{03403} & $70^{\circ} 11^{\prime} \mathrm{N}$ & 1943-1985 & 6477 & 2.60 & 101 & 11383 & 0.35 & 0.27 \\
\hline & $113^{\circ} 57^{\prime} \mathrm{E}$ & 1986-2002 & 3799 & 2.26 & 113 & 13587 & 0.26 & 0.29 \\
\hline \multirow[t]{2}{*}{03414} & $67^{\circ} 24^{\prime} \mathrm{N}$ & 1935 & 4390 & 4.32 & 42.0 & 2209 & 0.55 & 0.68 \\
\hline & $137^{\circ} 15^{\prime} \mathrm{E}$ & 1965-2002 & 4347 & 3.36 & 52.7 & 3425 & 0.48 & 0.68 \\
\hline \multirow[t]{2}{*}{03518} & $64^{\circ} 43^{\prime} \mathrm{N}$ & 1944-1985 & 6436 & 3.39 & 66.0 & 5243 & 0.47 & 0.38 \\
\hline & $144^{\circ} 37^{\prime} \mathrm{E}$ & 1986-2002 & 5167 & 2.61 & 86.9 & 8543 & 0.36 & 0.36 \\
\hline \multirow[t]{2}{*}{09425} & $65^{\circ} 58^{\prime} \mathrm{N}$ & 1941-1970 & 10047 & 2.12 & 233 & 56857 & 0.21 & 0.27 \\
\hline & $84^{\circ} 17^{\prime} \mathrm{E}$ & 1971-1999 & 10275 & 1.90 & 258 & 69485 & 0.20 & 0.27 \\
\hline \multirow[t]{2}{*}{11574} & $64^{\circ} 56^{\prime} \mathrm{N}$ & 1954-1970 & 6625 & 3.39 & 151 & 23906 & 0.21 & 0.86 \\
\hline & $77^{\circ} 48^{\prime} \mathrm{E}$ & 1971-2001 & 10408 & 3.17 & 152 & 24718 & 0.27 & 0.27 \\
\hline \multirow[t]{2}{*}{11805} & $65^{\circ} 39^{\prime} \mathrm{N}$ & 1955-1974 & 8398 & 3.02 & 156 & 25636 & 0.24 & 0.72 \\
\hline & $72^{\circ} 42^{\prime} \mathrm{E}$ & 1975-1991 & 13505 & 3.36 & 146 & 23220 & 0.31 & 0.66 \\
\hline \multirow[t]{2}{*}{70047} & $64^{\circ} 41^{\prime} \mathrm{N}$ & 1928-1958 & 12469 & 2.76 & 200 & 42164 & 0.24 & 0.21 \\
\hline & $39^{\circ} 32^{\prime} \mathrm{E}$ & 1959-1980 & 14391 & 3.56 & 147 & 23753 & 0.30 & 0.23 \\
\hline \multirow[t]{2}{*}{70153} & $60^{\circ} 12^{\prime} \mathrm{N}$ & $1931-$ & 7665 & 4.56 & 130 & 17612 & 0.22 & 0.46 \\
\hline & $47^{\circ} 00^{\prime} \mathrm{E}$ & 1947-1980 & 18536 & 4.10 & 140 & 21886 & 0.34 & 0.48 \\
\hline \multirow[t]{2}{*}{70180} & $61^{\circ} 52^{\prime} \mathrm{N}$ & 1930-1956 & 9022 & 3.34 & 165 & 28465 & 0.22 & -0.01 \\
\hline & $53^{\circ} 49^{\prime} \mathrm{E}$ & 1957-1980 & 11481 & 3.29 & 149 & 23969 & 0.28 & -0.01 \\
\hline \multirow[t]{2}{*}{70360} & $64^{\circ} 25^{\prime} \mathrm{N}$ & 1939-1958 & 25423 & 2.43 & 224 & 55552 & 0.32 & 0.38 \\
\hline & $41^{\circ} 03^{\prime} \mathrm{E}$ & 1959-1977 & 14897 & 3.14 & 170 & 31225 & 0.29 & 0.40 \\
\hline \multirow[t]{2}{*}{70366} & $64^{\circ} 59^{\prime} \mathrm{N}$ & 1927-1958 & 18073 & 3.49 & 128 & 18970 & 0.40 & 0.55 \\
\hline & $43^{\circ} 42^{\prime} \mathrm{E}$ & 1959-1980 & 12020 & 4.05 & 115 & 14749 & 0.33 & 0.51 \\
\hline \multirow[t]{2}{*}{70410} & $61^{\circ} 52^{\prime} \mathrm{N}$ & 1914-1930 & 10098 & 1.71 & 330 & 111916 & 0.16 & -0.06 \\
\hline & $56^{\circ} 57^{\prime} \mathrm{E}$ & 1931-1993 & 13730 & 2.04 & 253 & 67121 & 0.23 & -0.08 \\
\hline \multirow[t]{2}{*}{70414} & $62^{\circ} 57^{\prime} \mathrm{N}$ & 1938-1956 & 12960 & 1.96 & 307 & 97330 & 0.19 & 0.10 \\
\hline & $56^{\circ} 56^{\prime} \mathrm{E}$ & 1957-1980 & 8554 & 2.16 & 227 & 53351 & 0.20 & 0.15 \\
\hline \multirow[t]{2}{*}{70466} & $66^{\circ} 36^{\prime} \mathrm{N}$, & 1936-1957 & 18000 & 1.25 & 445 & 205006 & 0.19 & 0.29 \\
\hline & $60^{\circ} 52^{\prime} \mathrm{E}$ & 1958-1980 & 15331 & 1.32 & 367 & 140521 & 0.21 & 0.38 \\
\hline \multirow[t]{2}{*}{70509} & $63^{\circ} 49^{\prime} \mathrm{N}$ & 1933-1949 & 10124 & 2.46 & 217 & 49166 & 0.21 & 0.03 \\
\hline & $53^{\circ} 58^{\prime} \mathrm{E}$ & 1950-1980 & 8271 & 3.34 & 139 & 20651 & 0.25 & 0.03 \\
\hline \multirow[t]{2}{*}{70522} & $63^{\circ} 35^{\prime} \mathrm{N}$ & 1934-1949 & 10051 & 2.78 & 192 & 38779 & 0.22 & 0.19 \\
\hline & $53^{\circ} 51^{\prime} \mathrm{E}$ & 1950-1980 & 9630 & 3.72 & 127 & 17504 & 0.28 & 0.25 \\
\hline \multirow[t]{2}{*}{70531} & $65^{\circ} 17^{\prime} \mathrm{N}$ & 1937-1964 & 10545 & 3.77 & 147 & 22867 & 0.26 & 0.23 \\
\hline & $51^{\circ} 55^{\prime} \mathrm{E}$ & 1965-1980 & 12983 & 3.68 & 132 & 10205 & 0.32 & 0.30 \\
\hline
\end{tabular}


Table 2. Continued.

\begin{tabular}{llcrcrrrr}
\hline $\begin{array}{l}\text { Gauge } \\
\text { ID }\end{array}$ & Lat/long & Period & $\begin{array}{r}G_{\tilde{N} \mathrm{f}} \\
{\left[\mathrm{mm}^{2}\right]}\end{array}$ & $\bar{c}_{\mathrm{f}}$ & $\begin{array}{r}m_{1 \mathrm{f}} \\
{[\mathrm{mm}]}\end{array}$ & $\begin{array}{r}m_{2 \mathrm{f}} \\
{\left[\mathrm{mm}^{2}\right]}\end{array}$ & $\mathrm{CV}_{\mathrm{f}}$ & $\mathrm{CS}_{\mathrm{f}}$ \\
\hline 71104 & $68^{\circ} 56^{\prime} \mathrm{N}$, & $1928-1958$ & 9287 & 1.92 & 239 & 59383 & 0.21 & 0.13 \\
& $30^{\circ} 55^{\prime} \mathrm{E}$ & $1959-1994$ & 11647 & 2.26 & 155 & 26536 & 0.33 & 0.85 \\
\hline 71199 & $66^{\circ} 52^{\prime} \mathrm{N}$, & $1931-1958$ & 10865 & 2.30 & 207 & 45013 & 0.24 & 0.15 \\
& $33^{\circ} 20^{\prime} \mathrm{E}$ & $1959-1994$ & 11098 & 3.19 & 130 & 18606 & 0.32 & 0.24 \\
\hline 71241 & $67^{\circ} 18^{\prime} \mathrm{N}$, & $1934-1948$ & 5638 & 4.51 & 124 & 15878 & 0.20 & 0.53 \\
& $32^{\circ} 08^{\prime} \mathrm{E}$ & $1949-1980$ & 12086 & 4.32 & 104 & 1209 & 0.36 & 0.26 \\
\hline
\end{tabular}

Notations: $m_{1 \mathrm{f}}$ and $m_{2 \mathrm{f}}$ are the nominally predicted first and second statistical moments of the spring flood depth of runoff; $\mathrm{CV}_{\mathrm{f}}$ is the nominally predicted coefficient of variation; $\mathrm{CS}_{\mathrm{f}}$ is the nominally predicted coefficient of skewness; $\bar{c}_{\mathrm{f}}$ is the inverse of the runoff coefficient times the watershed reaction delay; $G_{\tilde{N} \mathrm{f}}$ characterizes the variability of the annual precipitation.

\section{Result and discussion}

The analysis of the expected climate change in Russia and particularly over the Arctic is provided by Govorkova et al. (2008) and Meleshko et al. (2008). These studies considered the territories of the Russian Federation as a whole. In our study, we provide the estimates for the geographical domain of the Russian Arctic, which was outlined according to the hydrological principles as suggested by Ivanov and Yankina (1991) and further used by Nikanorov et al. (2007). The projected climatology averaged over the Russian Arctic is presented in Table 4 for the SRES and RCP scenarios. Generally, an increase in annual precipitation of over $20 \mathrm{~mm}$ $(6 \%)$ and warming of over $2.1^{\circ} \mathrm{C}$ were predicted according to the SRES scenarios. For the RCP scenarios, the changes were more pronounced, with the precipitation mean values expected to increase by more than $40 \mathrm{~mm}$ (12\%), accompanied by a warming of $3.3^{\circ} \mathrm{C}$. The strongest increase (over $60 \mathrm{~mm}$ or $16 \%$ ) in precipitation with the highest warming (over $3.9^{\circ} \mathrm{C}$ ) was predicted by CaESM2 for the RCP2.6 scenario (Table 5).

The future means and CVs of the spring flood depth of runoff were assessed from the projected climatology using the method described above. For the entire territory of the Russian Arctic an increase of over $27 \mathrm{~mm}(17 \%)$ in the mean values and a slight decrease in CVs were predicted according to the SRES scenarios (Table 4). Using the scenarios of the Fifth Assessment Report, the changes in the statistics of the spring flood depth of runoff were more notable; based on the RCP2.6 scenario, an increase of over $38 \mathrm{~mm}(23 \%)$ in the mean values and a decrease of over $0.03(16 \%)$ in the CVs were expected. The strongest increase (over $45 \mathrm{~mm}$ or $27 \%$ ) in the means with the lowest decrease in the CVs (over 0.06 or $17 \%$ ) was predicted by CaESM2 for the RCP2.6 scenario.

According to all scenarios considered, the highest increase in the future means of the spring flood depth of runoff (of 30$35 \%$ ) was predicted for Arkhangelsk Oblast and the Komi Republic (Fig. 5b). Moderate changes in the mean values (of 10-18\%) are also predicted for Siberia (Fig. 5c and d), (a)

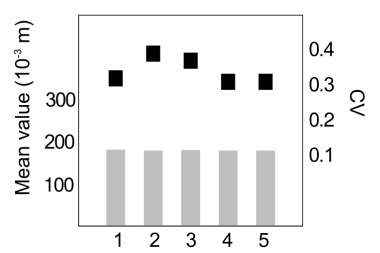

(c)

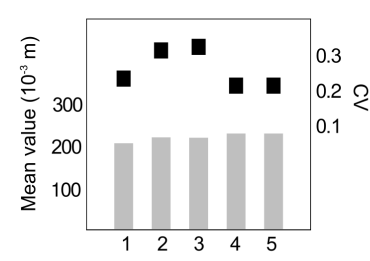

$\begin{array}{ll}\text { 1: The observations (1930-1980) } & \text { 2: SRES:A1B }\end{array}$ (b)

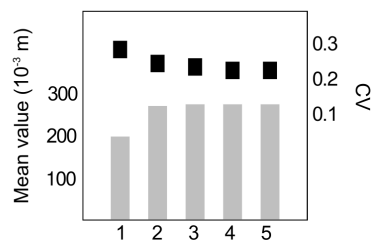

(d)

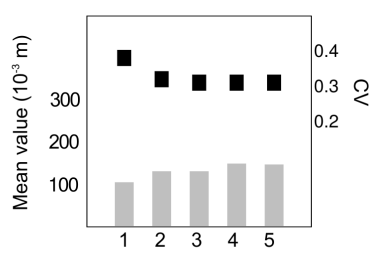

3: SRES:B1 4: RCP4.5 5: RCP2.6

Figure 5. The observed and projected the mean values (bars) and coefficients of variation (squares) of the spring flood depth of runoff expected for the regions of the Russian Arctic for the period 20102039: (a) the Kola Peninsula and Karelia; (b) Arkhangelsk Oblast and the Komi Republic; (c) West Siberia; (d) East Siberia.

mostly according to the RCP scenarios. For the SRES scenarios, an increase of 10-18\% in the mean values was predicted for the Kola Peninsula and Karelia (Fig. 5a), accompanied by a decrease in CVs.

We can not compare our results with other studies directly because we address different flooding characteristics. Only an indirect comparison is possible. For the comparison, we assume that for the Pearson type III distribution, an increase in the means and CVs leads to an increase in upper-tail values. Subsequently, present 100 -year floods will occur more frequently (Fig. 6). Also, a decrease in the means and CVs leads to a decrease in the upper-tail values. In this case, we can expect that the number of events of 100-year floods decreases. We compared our results with the studies by Hirabayashi et al. $(2008,2013)$, Lehner et 
Table 3. The percentage of successful fits between the nominally predicted and empirical PDFs according to the goodness-of-fit tests for 0.05 level of statistical significance.

\begin{tabular}{lcc}
\hline Version of the nominal prediction & $\begin{array}{c}\text { Kolmogorov-Smirnov } \\
\text { one-sample test }\end{array}$ & $\begin{array}{c}\text { Pearson } \\
\chi \text {-squared test }\end{array}$ \\
\hline No. model & 63 & 41 \\
\hline $\begin{array}{l}\text { Model with parameterization by Kovalenko } \\
\text { et al. (2010) }\end{array}$ & 67 & 51 \\
\hline $\begin{array}{l}\text { Model with regional-oriented parameterization } \\
\text { by Shevnina (2012) }\end{array}$ & 74 & 63 \\
\hline
\end{tabular}

Table 4. The reference (1930-1980) and projected climatology (2010-2039) and statistics of the spring flood depth of runoff averaged for the entire territory of the Russian Arctic.

\begin{tabular}{|c|c|c|c|c|c|}
\hline \multirow[t]{2}{*}{ Multi-year statistical values } & \multirow[t]{2}{*}{$\begin{array}{l}\text { Reference } \\
\text { climatology }\end{array}$} & \multicolumn{2}{|c|}{$\begin{array}{l}\text { Fourth Assessment } \\
\text { Report (AR4) }\end{array}$} & \multicolumn{2}{|c|}{$\begin{array}{l}\text { Fifth Assessment } \\
\text { Report (AR5) }\end{array}$} \\
\hline & & SRES:A1B & SRES:B1 & $\mathrm{RCP} 4.5$ & RCP2.6 \\
\hline $\begin{array}{l}\text { The annual precipitation mean } \\
\text { value }(\bar{N} \mathrm{~mm})\end{array}$ & 378 & 400 & 402 & 424 & 424 \\
\hline $\begin{array}{l}\text { The average annual air } \\
\text { temperature mean value }\left(\bar{T}^{\circ} \mathrm{C}\right)\end{array}$ & -10.3 & -8.2 & -8.2 & -6.9 & -7.2 \\
\hline $\begin{array}{l}\text { The spring flood depth of runoff } \\
\text { mean value }\left(m_{1} \mathrm{~mm}\right)\end{array}$ & 162 & 189 & 190 & 201 & 199 \\
\hline $\begin{array}{l}\text { The coefficient of variation of } \\
\text { the spring flood depth of runoff } \\
\text { (CV) }\end{array}$ & 0.30 & 0.30 & 0.29 & 0.29 & 0.25 \\
\hline
\end{tabular}

(a)

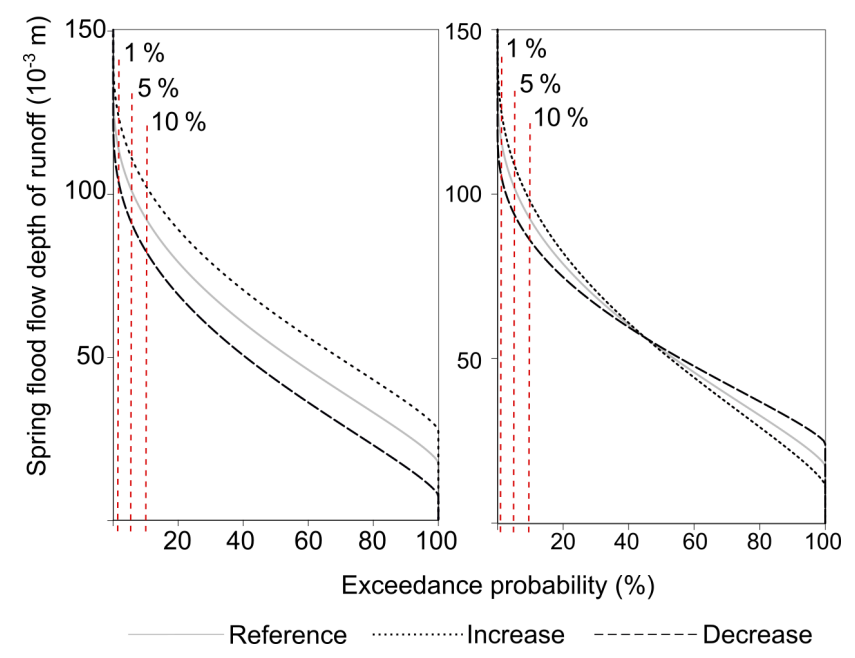

Figure 6. Schematic explanation of the changes in the upper-tail values due to changes in the parameters of the exceedance probability curve: (a) the mean value and (b) the coefficient of variation. al. (2006), and Dankers and Feyen (2008) using this assumption. For the eastern part of the Arctic, an increase in the historical 100-year maximum discharges is predicted by Hirabayashi et al. $(2008,2013)$ under the SRES:A1B scenario for the period 2001-2030. This is in accordance with our results; we also expect an increase in the upper-tail runoff values since the mean values and CVs were estimated to increase in general for this region. For the north-east European Arctic, we expect a significant increase in the frequency of present 100-year flood events. This is in contrast to Hirabayashi et al. (2013). The flood frequency decreases in many regions of northern and eastern Europe according to Hirabayashi et al. (2013). The feasible reason for such disagreement is that the model used by Hirabayashi et al. (2013) is very coarse; it was calibrated using observations from watersheds larger than $100000 \mathrm{~km}^{2}$. In our study, the probabilistic model was calibrated using observations for watersheds of medium range. Lehner et al. (2006) used the WaterGAP model with climate projections derived from the HadCM3 and ECHAM4/OPYC3 GCMs. The results suggest that present 100-year flood events will occur more frequently in the north-eastern European Arctic in the 2020s, which is in accordance with our results. 
Table 5. Projected (2010-2039) climatology and statistics of the spring flood depth of runoff averaged for the entire territory of the Russian Arctic according to the results of different climate models.

\begin{tabular}{lllcccc}
\hline Dataset & Scenario & GCM & $\begin{array}{c}\bar{N} \\
{[\mathrm{~mm}]}\end{array}$ & $\begin{array}{c}\bar{T} \\
{\left[{ }^{\circ} \mathrm{C}\right]}\end{array}$ & $\begin{array}{c}m_{1} \\
{[\mathrm{~mm}]}\end{array}$ & $\mathrm{CV}$ \\
\hline \multirow{2}{*}{ AR4 } & SRES:A1B & MPIM:ECHAM5 & 393 & -8.6 & 184 & 0.30 \\
& & HadCM3 & 403 & -7.9 & 191 & 0.30 \\
& & GFDL:CM2 & 404 & -8.2 & 192 & 0.29 \\
\cline { 3 - 7 } & \multirow{2}{*}{ SRES:B1 } & MPIM:ECHAM5 & 385 & -8.4 & 182 & 0.30 \\
& & HadCM3 & 405 & -8.1 & 191 & 0.30 \\
& & GFDL:CM2 & 415 & -8.2 & 196 & 0.28 \\
\hline \multirow{2}{*}{ AR5 } & \multirow{2}{*}{ RCP4.5 } & MPI-ESM & 421 & -6.9 & 201 & 0.26 \\
& & HadGEM2-A & 420 & -7.0 & 199 & 0.26 \\
& & CanESM2 & 436 & -6.7 & 204 & 0.25 \\
\cline { 3 - 7 } & \multirow{2}{*}{ RCP2.6 } & MPI-ESM & 415 & -7.2 & 197 & 0.26 \\
& & HadGEM2-A & 419 & -7.9 & 194 & 0.26 \\
& & CanESM2 & 438 & -6.4 & 207 & 0.24 \\
\hline
\end{tabular}

Notations: $\bar{N}$ is the mean annual precipitation; $\bar{T}$ is the mean annual air temperature; $m_{1}$ is the mean spring flood depth of runoff; $\mathrm{CV}$ is the coefficient of variation of the spring flood depth of runoff.

For the Kola Peninsula and Karelia, we predicted a decrease in the mean values with a slight increase in the CVs according to the SRES:A1B and SRES:B1 scenarios. Dankers and Feyen (2008) suggested a strong decrease in present 100-year floods for north-eastern Europe (i.e. Finland, northern Russia, and part of the Baltic States) under the SRES:A2 and SRES:B2 scenarios, which is generally in agreement with our results. A similar tendency of decreasing maximal discharges was predicted for northern Finland (Veijalainen et al., 2010).

There are several sources of uncertainties in the method described above: (1) from the assumed (given a priori) type of distribution (Pearson type III); (2) from the limited length of hydrological time series that were used to evaluate the parameters of the distribution for the reference period; (3) from the limited length of meteorological time series to evaluate the climatology for the model parameterization; (4) from the uncertainties in future climatology provided by climate models (forcing); (5) from the mapping errors due to interpolation techniques; and (6) from the errors due to the calculation of the maximal discharges from the spring flood depth of runoff (Eq. 1). The uncertainties inherent in the simulated PDF parameters include items 1-5 from the list above. These uncertainties are evaluated by Kovalenko (1993) for the maps of means/CVs provided by Rogdestvenskiy (1986) and Vodogretskiy (1986) with the assumption that the errors in the future and past climatology are the same. The average percentage errors in the projected means/CVs are equal to $15 / 25 \%$; thus, it suggests considering the changes in the PDF parameters to be substantial if they exceed the reference values for more than these thresholds. The regions with substantial changes in the means and CVs of the spring flood flow depth are shown in Fig. 7.
In these regions, the frequency and magnitude of floods were predicted to differ substantially from the historical (reference) period. The changes in the mean values and coefficients of variation were predicted according to the outputs of the climate models of the Max Planck Institute for Meteorology: MPIM:ECHAM5 for the SRES:B1 scenario and MPIESM-LR for the RCP2.6 scenario. A substantial increase in the mean values is expected for Arkhangelsk Oblast, Komi Republic, and eastern Siberia (see Fig. 8 for the boundary of the regions). These are warning regions where the floodrelated risks for hydraulic constructions in the future may be different from the past. In these regions, calculations of the maximal discharges should be corrected in line with the expected climate change.

As an example, the climate-based correction for the Nadym River at Nadym, according to climate model outputs for the RCP2.6 scenario, is given below. A new bridge over the Nadym River was constructed in 2015 and repaired after the spring flood in 2016. The maximal discharge of rare occurrence (e.g. $1 \%$ exceedance probability) is required to assess the bridge height and cost. The watershed of the Nadym River is located in the region, where the increase in the mean spring flood depth of runoff was predicted under RCP2.6 scenario (Fig. 7, right, upper panel). Thus, the climate change impacted upper-tail maximal discharge may be considerably larger than the value estimated from the observed time series. Hydrological observations for the Nadym River are available at Nadym (gauge number 11805, the watershed area is $48000 \mathrm{~km}^{2}$; see the bottom panel of Fig. 8). The statistics of the spring flood depth of runoff for this gauge were calculated from observations in the period 19541980, which was considered as the reference in this case (Table 6). The reference climatology was calculated by averag- 
Table 6. Climatology and the statistics of the extreme flood runoff for the Nadym River at Nadym evaluated from the observations and under the climate projection RCP2.6 for the period 2010-2039.

\begin{tabular}{lrrrrr}
\hline Multi-year values & Period of & \multicolumn{4}{c}{ Result according to GCM } \\
\cline { 3 - 6 } & $1954-1980$ & HadGEM2-A & MPI-ESM-LR & CanESM2 & Multi-model \\
\hline $\bar{N} \mathrm{~mm}$ & 431 & 483 & 491 & 519 & 498 \\
$\bar{T}{ }^{\circ} \mathrm{C}$ & -5.9 & -4.0 & -2.9 & -2.4 & -3.1 \\
$m_{1} \mathrm{~mm}$ & 160 & 180 & 184 & 197 & 187 \\
$\mathrm{CV}$ & 0.28 & 0.25 & 0.23 & 0.19 & 0.22 \\
$h_{1} \% \mathrm{~mm}$ & 277 & 297 & 293 & 297 & 296 \\
$Q_{1} \% \mathrm{~m}^{3} \mathrm{~s}^{-1}$ & 8572 & 9177 & 9062 & 9191 & 9144 \\
\hline
\end{tabular}

Notations: $\bar{N}$ is the mean annual precipitation; $\bar{T}$ is the mean annual air temperature; $m_{1}$ is the mean spring flood depth of runoff; $\mathrm{CV}$ is the coefficient of variation of the spring flood depth of runoff, $h_{1} \%$ is the spring flood depth of runoff with exceedance of $1 \%, Q_{1} \%$ is the maximal discharge with exceedance probability of $1 \%$.
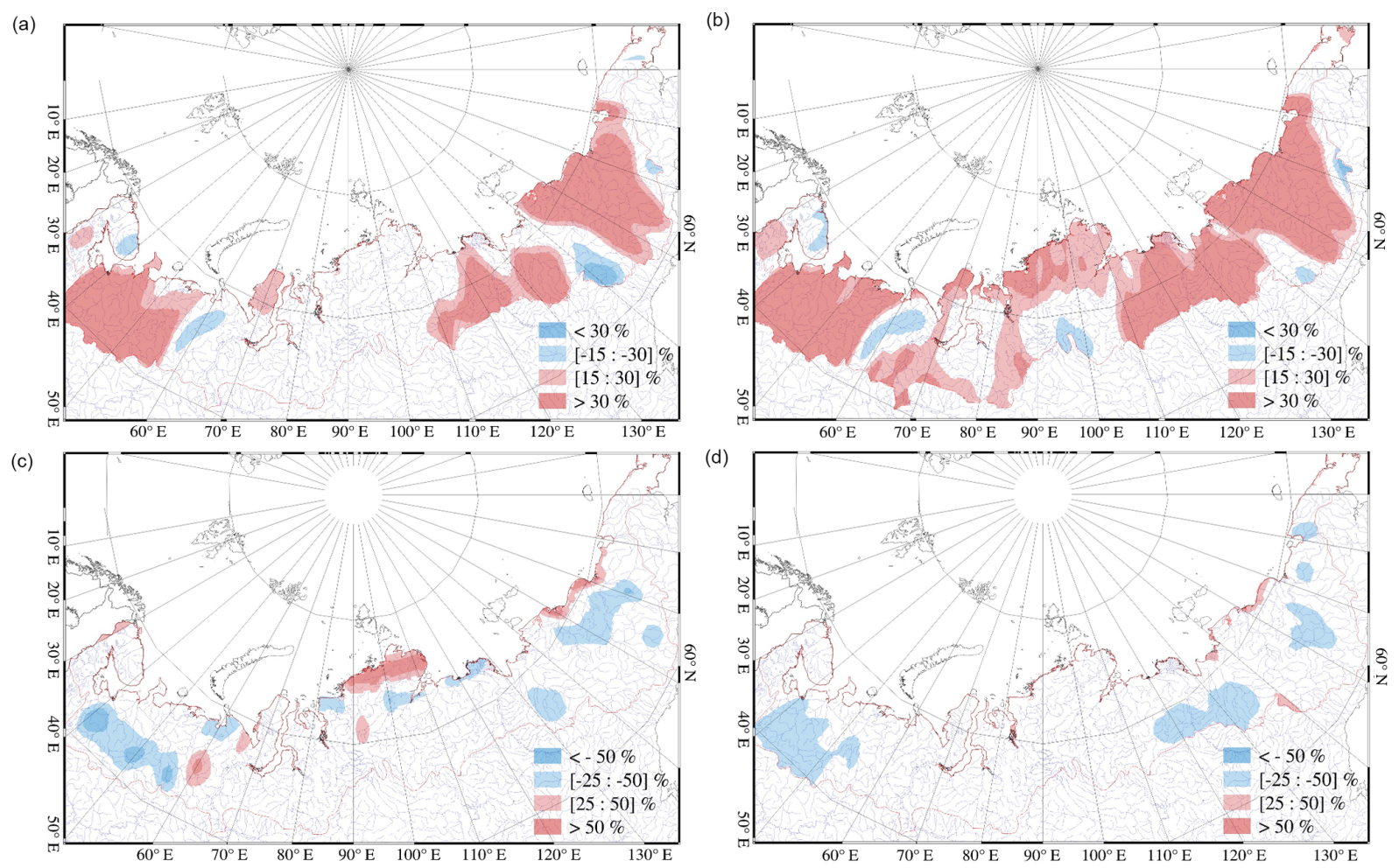

Figure 7. The regions with substantial changes in the mean values (a, b) and coefficients of variation (c, d) of the spring flood depth of runoff according to the MPIM:ECHAM5 under the SRES:B1 (a, c) scenario and the MPI-ESM-LR under the RCP2.6 scenario (b, d).

ing the observations from the regular meteorological sites for the Nadym River catchment area for the same period. Then, the projected climatology with delta correction for the period 2010-2039 under the RCP2.6 scenario was obtained from the CMIP5 dataset. The parameter $G_{\widetilde{N}}$ was estimated according to the observed climatology and the parameter $\bar{c}$ was calculated from the projected climatology according to Shevnina (2012). These values were used to predict the first and second initial statistical moments, and the coefficient of variation $\left(m_{1}, m_{2}\right.$ and $\left.\mathrm{CV}\right)$ of the spring flood depth of runoff. The projected CS was estimated from the given ra- tio of CS / CV. The projected PDF was obtained from these values together with the spring flood depth of runoff $1 \%$ exceedance probability $\left(h_{1} \%, \mathrm{~mm}\right)$ (Table 6$)$. The confidence intervals for the reference values of $h_{1} \%$ were calculated using the formulas suggested by Ashkar and Bobée (1988) with the assumption that the given distribution is Pearson type III. The $90 \%$ confidence interval for the reference $h_{1} \%$ equal to $\pm 64.5 \mathrm{~mm}$, which is about $23 \%$ of the quantile value. The projected values of $h_{1} \%$ are within these uncertainties for all considering climate scenarios (Table 6); thus, due to the short time series we can not prove that the future changes 


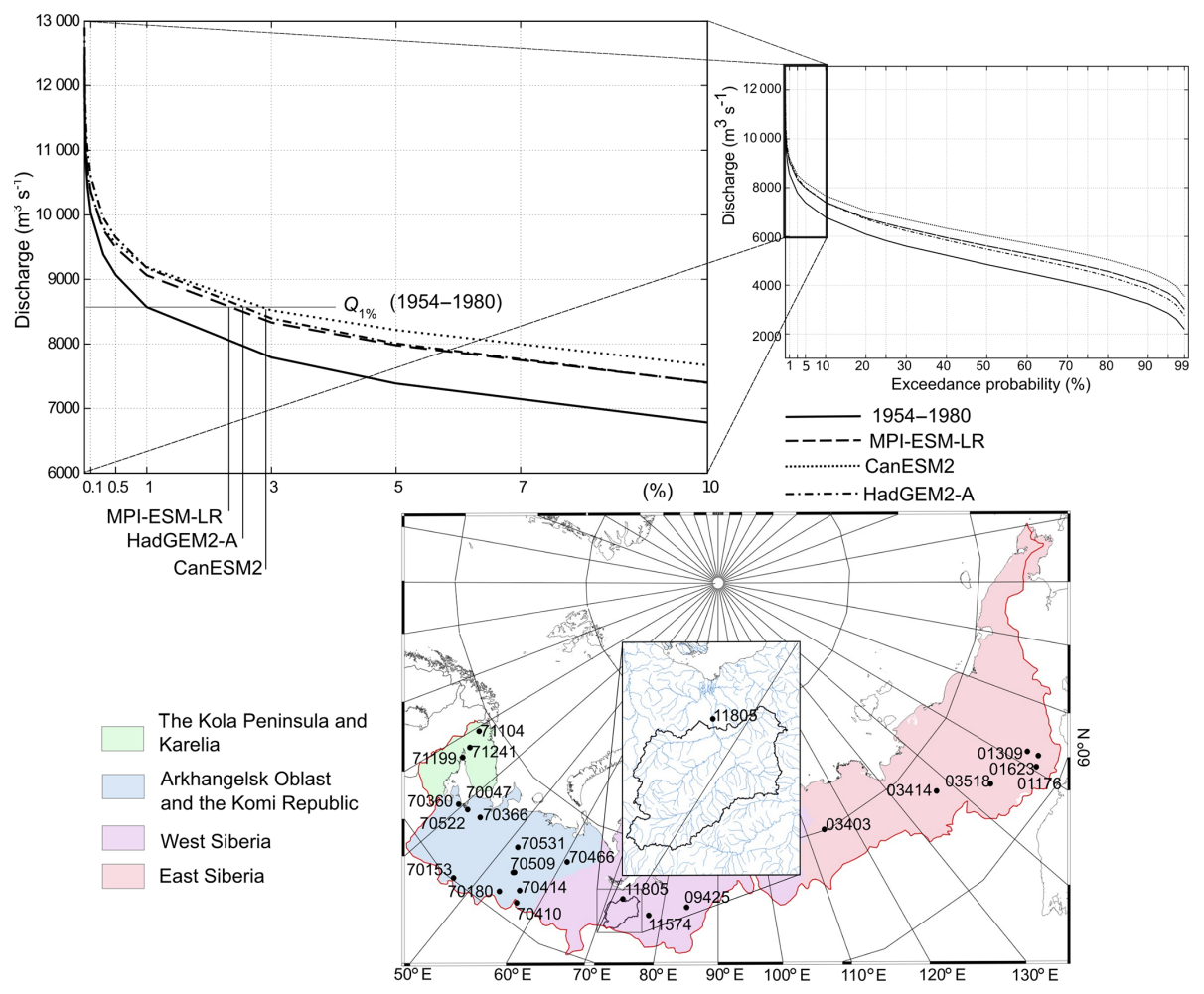

Figure 8. (a) The exceedance probability curves of the peak-flow discharge for the period 1954-1980 and for the projected period 2010-2039 under the RCP2.6 scenario for the Nadym River at Nadym (11805). (b) The considered regions of the Russian Arctic, the watershed of the Nadym River and location of the gauges used for the model cross-validation.

in $h_{1} \%$ are statistically insignificant. However, we suggest taking it into account for the projected climatology when calculating hydrological risks due to practical reasons; it is better to prevent a disaster rather than to deal with its consequences, which may be more expensive than the initial investment (Räisänen and Palmer, 2001). Finally, the maximal discharge with $1 \%$ exceedance probability $\left(Q_{1} \%, \mathrm{~m}^{3} \mathrm{~s}^{-1}\right)$ was estimated from $h_{1} \%$ according to Eq. (1). The values of the parameters in Eq. (1) were taken from the look-up tables (Guideline to estimate hydrological characteristics, 1984). The value of $k_{0}$ was considered to be constant for the reference and projected periods and set to be equal to 1 in our example, for the sake of simplicity; $\mu$ is equal to $1.0 ; \delta, \delta_{1}$, $\delta_{2}$ are equal to $0.84,0.06$, and 0.08 correspondingly; $b$ equals $1.0\left(\mathrm{~km}^{2}\right)$, and $n$ equals 0.17 .

For the period 2010-2039, the maximal discharge of $1 \%$ exceedance probability, which was calculated with averaging of the multi-model output, is $570 \mathrm{~m}^{3} \mathrm{~s}^{-1}$ larger than the discharge of the same probability of exceedance, which was calculated from the observations. The largest increase in the maximal discharge was predicted according to the CanESM2 model (over $7 \%$ larger than the historical value). The maximal discharge of $8572 \mathrm{~m}^{3} \mathrm{~s}^{-1}$ changed the probability of exceedance from $1 \%$ (calculated from the observations) to
$2.5 \%$ (calculated according to the averaged climate projections).

\section{Conclusions}

A probabilistic approach was applied in estimating the impact of climate change on the frequency and magnitude of extreme floods in the Russian Arctic. The projected meteorological mean values for periods of 20-30 years were used to estimate the future means, CVs and CSs of the spring flood depth of runoff, and to model the PDFs with a Pearson type III distribution. The future frequency and magnitude of extreme floods with a required exceedance probability were then evaluated from the simulated PDFs.

In this study, to perform the model cross-validation, the runoff data were extracted from the official issues of Roshydromet; however, in calculating multi-year time series of spring flood depth of runoff (and maximal discharge), the global and regional runoff databases may also be used. The examples of the datasets are (i) the Global Runoff Data Centre, Germany; (ii) the Environmental Information System (HERTTA), Finnish Environment Institute; and the Vattenwebb by the Swedish Meteorological and Hydrological Institute. To perform the assessments for other regions, the steps are as follows: (i) to choose the middle size watersheds 
with a catchment area from 1000 to $50000 \mathrm{~km}^{2}$; (ii) to calculate the multi-year time series of runoff (yearly maximal discharges or spring flood depth of runoff) from the daily runoff time series; (iii) to select the time period without statistically significant trends (reference period); (iv) to estimate the mean values, CVs, and CSs from the observed time series of runoff or to evaluate them from the regional maps (i.e. Spence and Burke, 2008) and the statistics of the precipitation and air temperature; (v) to perform the model parameterization using general (Kovalenko et al., 2010) or regionaloriented schemes (Shevnina, 2012); (vi) to assess the mean values of the precipitation and air temperature from the results of the GCM/RCM models for the future; and (vii) to evaluate the future means, CVs, and CSs of multi-year runoff with Eq. (4). To perform the model cross-validation and to develop the regional-oriented parameterization scheme, the multi-year time series of runoff with periods of statistically significant shifts in the mean values and CVs are required.

The probabilistic model was further applied for a regionalscale assessment of extreme flood events for the Russian Arctic. The regional-oriented parameterization by Shevnina (2012) allows for a successful prediction of $67-83 \%$ of the PDFs (see Sect. 2.2). The projected mean values, CVs, and CSs of the spring flood depth of runoff for the period 2010-2039 were estimated under the SRES:A1B, SRES:B1, RCP2.6, and RCP4.5 climate scenarios with outputs of three climate models. For the region studied, an increase of $17-23 \%$ in the mean values of spring flood depth of runoff and a decrease of 5-16\% in the CVs were predicted depending on the scenarios considered. For the north-west Russian Arctic, an increase in the means and a decrease in the $\mathrm{CVs}$ were predicted. The regions with substantial changes in the mean values (over $15 \%$ ) and CVs (over $25 \%$ ) were defined for 2010-2039. For territories where the means and CVs increased substantially, extreme floods are predicted to occur more frequently and the risk of flooding is increased. We suggest correcting the hydrological engineering calculations and accounting for the projected climatology. This might reduce the risk of a potential hazard for hydraulic construction, the oil and gas industry, transport infrastructure, and population located in these threatened regions.

The model presented in this study provides an affordable method to produce forecasts of extreme flood events (in the form of PDF or as maximal discharge with a required exceedance probability) under the projected climate change scenarios. This is possible due to the low numbers of simulated variables and parameters. The regionally oriented parameterization of the model is also relatively simple and may be improved by involving a variance of precipitation, which could be obtained from the projected climatology (Meehl and Bony, 2011). However, due to various simplifications, the model presented in this study does not allow for an estimation of possible changes in spring flood timing or changes of intra-seasonal runoff variability for a particular watershed. On a regional scale, however, the method provides an ex- plicit advantage in estimating extreme hydrological events under altered climate, especially for regions with insufficient observational data. It could be useful for a broad-scale assessment to define the threatened regions where a crucial increase/decrease in the extreme flood events is expected. When the warning regions are defined, a catchment-scale rainfall-runoff model could be applied to further distinguish details not anticipated by the method described in this study. Such models also allow for evaluating the value of the spring flood coincidence factor $k_{0}$ (Eq. 1) for the projected periods (which was constant in our calculations). The evaluation and inter-comparison of the presented model and rainfall-runoff models is of high interest.

Another weak point of the method is the use of lookup tables for physiographic parameters. In our study, to calculate the extreme discharges of the Nadym River we used look-up tables for the territory of the former Soviet Union from Guideline to estimate basic hydrological characteristics (1984). For other regions worldwide, these physiographic parameters may be derived from spatially distributed datasets, e.g. according to Bartholomé and Belward (2005). Also, an issue to be studied is the effect of the spatial resolution of projected climatology on the ability of this model to estimate the frequency/magnitude of extreme floods for watersheds of different sizes.

The method described in this study was simplified for the use of engineering calculations, as the projected climatology for periods of 20-30 years as recommended by the IPCC (Pachauri and Reisinger, 2007) assumes a quasi-stationary climate. In general, the quasi-stationarity assumption may be eliminated and a non-stationary regime could be considered. In this case, the PDFs could be evaluated based on the full form of the Fokker-Planck-Kolmogorov equation (Domínguez and Rivera, 2010) with the multi-model climate ensemble approach (Tebaldi and Knutti, 2007).

Data availability. Our study is based on third party data. The citations to the datasets have been included in the reference list. 


\section{Appendix A: Basic model and simplifying assumptions}

The concept of probabilistic modelling to obtain a hydrological response to an expected climate change was proposed by Kovalenko (1993), it is presented further as provided in Kovalenko et al. (2010). This approach considers multi-year runoff time series (annual, maximal, and minimal) as realizations of a stochastic process of the Markov chain type (Rogdestvenskiy, 1988). Then, a first-order ordinary differential equation is used as a lumped hydrological model for the multi-year flow time series:

$\mathrm{d} Q / \mathrm{d} t=-(1 / k \tau) Q+\dot{X} / \tau$,

where $Q$ is some runoff characteristic depending on a task (the discharge, the runoff volume per year, the runoff depth per year, etc. - "model output"); $\dot{X}$ is the precipitation per year ("model input"); $k$ is the runoff coefficient; $\tau$ is the time of reaction of the watershed to the incoming precipitation (here, $\tau=1$ year, which physically means that the precipitation during 1 year generates the runoff from the watershed during 1 year); $t$ is the time interval, equal to 1 year. Denoting $c=1 / k \tau$ and $N=\dot{X} / \tau$, and adding random components $(\widetilde{c}, \widetilde{N}$ stand for "white noise") to $c=\bar{c}+\widetilde{c}$ and $N=\bar{N}+\widetilde{N}$, we obtain the stochastic differential equation:

$\mathrm{d} Q=[-(\bar{c}+\widetilde{c}) Q+(\bar{N}+\widetilde{N})] \mathrm{d} t$.

The random components are mutually correlated.

The solution of Eq. (A2) is statistically equivalent to the solution of the Fokker-Planck-Kolmogorov equation (Pugachev et al., 1974):

$$
\begin{aligned}
\frac{\partial p(Q, t)}{\partial t} & =-\frac{\partial}{\partial Q}(A(Q, t) p(Q, t)) \\
& +0.5 \frac{\partial^{2}}{\partial Q^{2}}(B(Q, t) p(Q, t)),
\end{aligned}
$$

where $p(Q, t)$ is the probability density function of the multi-year runoff characteristic $(Q$ is considered now as a random value); $A(Q, t)$ and $B(Q, t)$ are the drifting and diffusion coefficients:

$$
\begin{aligned}
& A(Q, t)=-\left(\bar{c}-0.5 G_{\widetilde{c}}\right) Q-0.5 G_{\widetilde{c} \widetilde{N}}+\bar{N}, \\
& B(Q, t)=G_{\widetilde{c}} Q^{2}-2 Q G_{\widetilde{c} \widetilde{N}}+G_{\widetilde{N}},
\end{aligned}
$$

here, $G_{\tilde{c}}$ and $G_{\tilde{N}}$ are the measures of variability of $c$ and $N$; $G_{\widetilde{c} \widetilde{N}}$ is the measure of correlation between the variability of $G_{\tilde{c}}$ and $G_{\tilde{N}}$.

In engineering hydrological applications and flood frequency analysis, only three parametric probability density functions are used (Bulletin 17-B, 1982). Then Eq. (A3) may be simplified to a system of ordinary differential equations for three statistical moments $m_{i}(i=1,2,3)$ :

$$
\begin{aligned}
\mathrm{d} m_{1} / \mathrm{d} t & =-\left(\bar{c}-0.5 G_{\widetilde{c}}\right) m_{1}-0.5 G_{\widetilde{c} \widetilde{N}}+\bar{N}, \\
\mathrm{~d} m_{2} / \mathrm{d} t & =-2\left(\bar{c}-G_{\widetilde{c}}\right) m_{2}+2 \bar{N} m_{1}-3 G_{\widetilde{c} \widetilde{N}} m_{1}+G_{\widetilde{N}}, \\
\mathrm{~d} m_{3} / \mathrm{d} t & =-3\left(\bar{c}-1.5 G_{\widetilde{c}}\right) m_{3}+3 \bar{N} m_{2}-7.5 G_{\widetilde{c} \widetilde{N}} m_{2} \\
& +3 G_{\widetilde{N}} m_{1} .
\end{aligned}
$$

This system can be used to calculate the statistics of the multi-year runoff: the mean $\bar{Q}=m_{1}$, the coefficient of variation $\mathrm{CV}=\sqrt{\left(m_{2}-m_{1}^{2}\right)} / m_{1}$, and the coefficient of skewness $\mathrm{CS}=\left(m_{3}-3 m_{2} m_{1}+2 m_{1}^{3}\right) /\left(\mathrm{CV}^{3} m_{1}^{3}\right)$. In this study, the constant value of the $\mathrm{CS} / \mathrm{CV}$ ratio for the projected time period was used to simplify Eq. (A5). This assumption is commonly applied in engineering hydrological applications to estimate the regional CS (Guideline to estimate basic hydrological characteristics, 1984). Also, the climate scenarios are distributed by IPCC as mean values of meteorological variables for periods of 20-30 years. Thus, scenarios for the expected climate change are presented with an assumption of "quasi-stationarity" and this may also be applied to the hydrological regime. This allows for further simplifications of Eq. (A5): $\mathrm{d} m_{i} / \mathrm{d} t \approx 0$ and $G_{\tilde{c}}, G_{\tilde{c} \widetilde{N}}=0$ within these periods. Hence, Eq. (A5) may be reduced to only two algebraic equations for $m_{1}$ and $m_{2}$ :

$-\bar{c} m_{1}+\bar{N}=0$,

$-2 \bar{c} m_{2}+2 \bar{N} m_{1}+G_{\tilde{N}}=0$.

This system may be applied to estimate the multi-year hydrological statistical moments directly from climatology for each "quasi-stationary" time period. 
Competing interests. The authors declare that they have no conflict of interest.

Acknowledgements. This study was funded through the Ministry of Education and Science of the Russian Federation (project 1413) and supported by the Academy of Finland (contract 283101). The article processing charges for this open-access publication were covered by the Academy of Finland. The authors are very thankful to the reviewers of BER and HESS, who provided very useful comments and suggestions for improving the manuscript. Our special thanks to Lynn.

Edited by: C. De Michele

Reviewed by: F. Serinaldi, I. Fedorova, and one anonymous referee

\section{References}

Archeimer, B. and Lindström, G.: Climate impact on floods: changes in high flow in Sweden in the past and the future (19112100), Hydrol. Earth Syst. Sci., 19, 771-784, doi:10.5194/hess19-771-2015, 2015.

Ashkar, F. and Bobée, B.: Confidence intervals for flood events under a Pearson 3 or log Pearson 3 distribution, J. Am. Water Resour. Assoc., 24, 639-650, doi:10.1111/j.17521688.1988.tb00916.x, 1988.

Benson, M. A.: Uniform flood frequency estimating methods for federal agencies, Water Resour. Res., 4, 891-908, 1968.

Bertholomé, E. and Belward, A. S.: GLC2000: a new approach to global land cover mapping from Earth observation data, Int. J. Remote Sens., 26, 1959-1977, doi:10.1080/01431160412331291297, 2005.

Bowman, K. O. and Shenton, L. R.: Estimator: Method of Moments, in: Encyclopedia of statistical sciences, Wiley, New York, 20922098, 1998.

Bulletin 17-B: Guideline for determining flood flow frequency, US Geological Survey, Virginia, 1982.

Catalogue of Climatology of USSR: Serie 3: multi-year data, Gidrometeoizdat, Leningrad, 1989.

Collins, M., Knutti, R., Arblaster, J., Dufresne, J.-L., Fichefet, T., Friedlingstein, P., Gao, X., Gutowski, W. J., Johns, T., Krinner, G., Shongwe, M., Tebaldi, C., Weaver, A. J., and Wehner, M.: Long-term Climate Change: Projections, Commitments and Irreversibility, in: Climate Change: The Physical Science Basis, Contribution of Working Group I to the Fifth Assessment Report of the Intergovernmental Panel on Climate Change, Cambridge University Press, Cambridge, UK and New York, 1029-1136, 2013.

Collins, W. J., Bellouin N., Doutriaux-Boucher, M., Gedney N., Hinton, T., Jones, C. D., Liddicoat, S., O'Connor, M. G. F., Rae, J., Senior, C., Totterdell, I., Woodward, S., Reichler, T., and Kim, J.: Evaluation of the HadGEM2 model, Technical Note no. HCTN 74, Met Office Hadley Centre, Exeter, UK, 2008.

Dankers, R. and Feyen, L.: Climate change impact on food hazard in Europe: an assessment based on high-resolution climate simulations, J. Geophys. Res.-Atmos., 113, D19105, doi:10.1029/2007JD009719, 2008.
Delworth, T. L., Broccoli, A. J., Rosati, A., Stouffer, R. J., Balaji, V., Beesley, J. A., Cooke, W. F., Dixon, K. W., Dunne, J., Dunne, K. A., Durachta, J. W., Findell, K. L., Ginoux, P., Gnanadesikan, A., Gordon, C. T., Griffies, S. M., Gudgel, R., Harrison, M. J., Held, I. M., Hemler, R. S., Horowitz, L. W., Klein, S. A., Knutson, T. R., Kushner, P. J., Langenhorst, A. R., Lee, H.-C., Lin, S.-J., Lu, J., Malyshev, S. L., Milly, P. C. D., Ramaswamy, V., Russell, J. M., Schwarzkopf, D., Shevliakova, E., Sirutis, J. J., Spelman, M. J., Stern, W. F., Winton, M., Wittenberg, A. T., Wyman, B., Zeng, F., and Zhang, R.: GFDL's CM2 global coupled climate models. Part 1: Formulation and simulation characteristics, J. Climate, 19, 643-674, doi:10.1175/JCLI3629.1, 2006.

Domínguez, E. and Rivera, H.: A Fokker-Planck-Kolmogorov equation approach for the monthly affluence forecast of Betania hydropower reservoir, J. Hydroinform., 12, 486-501, doi:10.2166/hydro.2010.083, 2010.

Ducré-Robitaille, J.-F., Vincent, L. A., and Boulet, G.: Comparison of techniques for detection of discontinuities in temperature series, Int. J. Climatol., 23, 1087-1101, doi:10.1002/joc.924, 2003.

Elderton, S. W. P. and Johnson, N. L.: Systems of Frequency Curves, Cambridge University Press, London, 1969.

Fowler, H. J., Blenkinsop, S., and Tebaldi, C.: Linking climate change modeling to impacts studies: recent advances in downscaling techniques for hydrological modelling, Int. J. Climatol., 27, 1547-1578, 2007.

Gazprom: http://www.gazprom.com/about/production/projects/ mega-yamal, last aaccess: 25 April 2017.

Giorgetta, M., Jungclaus, J., Reick, C., Legutke, S., Bader, J., Böttinger, M., Brovkin, V., Crueger, T., Esch, M., Fieg, K., Glushak, K., Gayler, V., Haak, H., Hollweg, H.-D., Ilyina, T., Kinne, S., Kornblueh, L., Matei, D., Mauritsen, T., Mikolajewicz, U., Mueller, W., Notz, D., Pithan, F., Raddatz, T., Rast, S., Redler, R., Roeckner, E., Schmidt, H., Schnur, R., Segschneider, J., Six, K., Stockhause, M., Timmreck, C., Wegner, J., Widmann, H., Wieners, K.-H., Claussen, M., Marotzke, J., and Stevens, B.: Climate and carbon cycle changes from 1850 to 2100 in MPI-ESM simulations for the coupled model intercomparison project phase 5. J. Adv. Model. Earth Syst., 5, 572-597, doi:10.1002/jame.20038, 2013.

Govorkova, V. A., Katsov, V. M., Meleshko, V. P., Pavlova, T. V., and Shkol'nik, I. M.: Climate of Russia in the 21st Century. Part 2. Verification of atmosphere-ocean general circulation models CMIP3 for projections of future climate changes, Russ. Meteorol. Hydrol., 33, 467-477, doi:10.3103/S106837390809001X, 2008.

Guideline to estimate basic hydrological characteristics, Gidrometeoizdt, Leningrad, 1984.

Hirabayashi, S., Kanae, S., Emori, T., Oki, T. and Kimoto, M.: Global projections of changing risks of foods and droughts in a changing climate, Hydrolog. Sci. J., 53, 754-773, doi:10.1623/hysj.53.4.754, 2008.

Hirabayashi, Y., Mahendran, R., Koirala, S., Konoshima, L., Yamazaki, D., Watanabe, S., Kim, H., and Kanae, S.: Global flood risk under climate change, Nat. Clim. Change, 3, 816-821, doi:10.1038/nclimate1911, 2013.

Hofierka, J., Parajka, J., Mitasova, H., and Mitas, L.: Multivariate interpolation of precipitation using regularized spline with tension, Trans. GIS, 6, 135-150, doi:10.1111/1467-9671.00101, 2002. 
IPCC: The Physical Basis, Annex I: Atlas of Global and Regional Climate Projections, Cambridge University Press, New York, 2013.

Ivanov, V. and Yankina, V.: Water resources of the Arctic: the past and future aims of research, Problem Arct. Antarct., 66, 118-128, 1991

Johns, T. C., Gregory, J. M., Ingram, W. J., Johnson, C. E., Jones, A., Lowe, J. A., Mitchell, J. F. B., Roberts, D. L., Sexton, B. M. H., Stevenson, D. S., Tett, S. F. B., and Woodage, M. J.: Anthropogenic climate change for 1860 to 2100 simulated with the HadCM3 model under updated emissions scenarios, Clim. Dynam., 20, 583-612, doi:10.1007/s00382-002-0296-y, 2003.

Kharin, V. V., Zwiers, F. W., Zhang, X., and Wehner, M.: Changes in temperature and precipitation extremes in the CMIP5 ensemble, Climatic Change, 119, 345-357, doi:10.1007/s10584-013-07058, 2013.

Kite, G. W.: Frequency and risk analysis in hydrology, Water Resources Publications, Fort Collins, Colorado, 1977.

Kovalenko, V. V.: Modeling of hydrological processes, Gidrometizdat, Saint-Peterburg, 1993.

Kovalenko, V. V.: Using a probability model for steady long-term estimation of modal values of long-term river runoff characteristics, Russ. Meteorol. Hydrol., 39, 57-62, doi:10.3103/S1068373914010099, 2014.

Kovalenko, V. V., Victorova, N. V., Gaydukova, E. V., Gromova, M. A., Khaustov, V. A., and Shevnina, E. V.: Guideline to estimate a multi-year runoff regime under non-steady climate to design hydraulic contractions, RSHU, Saint-Petersburg, 2010.

Krasting, J. P., Broccoli, A. J., Dixon, K. W., and Lanzante J. R.: Future Changes in Northern Hemisphere Snowfall, J. Climate, 26, 7813-7828, doi:10.1175/JCLI-D-12-00832.1, 2013.

Kritsky, S. N. and Menkel, M. F.: On the methods of studying the random variations of river flow, Gidrometeoizdat, Leningrad, 1946.

Kuchment, L. S. and Gelfan, A. N.: Assessment of extreme flood characteristics based on a dynamic-stochastic model of runoff generation and the probable maximum discharge, J. Flood Risk Manage., 4, 115-127, doi:10.1111/j.1753-318X.2011.01096.x, 2011.

Kuznetsov, I. V. (Ed.): Multi-year book of basic hydrological characteristics, Gidrometeoizdat, Leningrad, 1966.

Laine, A., Nakamura, H., Nishii, K., and Miyasaka T.: A diagnostic study of future evaporation changes projected in CMIP5 climate models, Clim. Dynam., 42, 2745-2761, doi:10.1007/s00382014-2087-7, 2014.

Lawrence, D. and Haddeland, I.: Uncertainty in hydrological modeling of climate change impacts in four Norwegian catchments, Hydrol. Res., 42, 457-471, doi:10.2166/nh.2011.010, 2011.

Lehner, B., Döll, P., Alcamo, J., Henrichs, H., and Kaspar, F.: Estimating the impact of global change on flood and drought risks in Europe: a continental, integrated analysis, Climatic Change, 75, 273-299, doi:10.1007/s10584-006-6338-4, 2006.

Lins, H. F. and Cohn, T. A.: Stationarity: Wanted Dead or Alive?, J. Am. Water Resour. Assoc., 47, 475-480, doi:10.1111/j.17521688.2011.00542.x, 2011.

Mackenzie gas project: http://www.mackenziegasproject.com, last aaccess: 2 February 2017.

Madsen, H., Lawrence, D., Lang, M., Martinkova, M.,, and Kjeldsen, T. R.: A review of applied methods in Europe for flood- frequency analysis in a changing environment, NERC/Centre for Ecology \& Hydrology on behalf of COST, available at: http: //nora.nerc.ac.uk/501751/ (last aaccess: 2 February 2017), 2013.

Meehl, G. A. and Bony, S.: Introduction to CMIP5, CLIVAR Exchanges Newslett., 56, 2-5, 2011.

Meleshko, V. P., Katsov, V. M., Govorkova, V. A., Sporyshev, P. V., Shkol'nik, I. M., and Shneerov, B. E.: Climate of Russia in the $21^{\text {st }}$ century. Part 3 . Future climate changes calculated with an ensemble of coupled atmosphere-ocean general circulation CMIP3 models, Russ. Meteorol. Hydrol., 33, 541-552, doi:10.3103/S106837390809001X, 2008.

Milly, P., Betancourt, J., Falkenmark, M., Hirsch, R. M., Kundzewicz, Z. W., Lettenmaier, D. P., and Stouffer, R. J.: Stationarity is dead: whither water management, Science, 319, 573574, doi:10.1126/science.1151915, 2008.

Montanari, A. and Koutsoyiannis, D.: Modeling and mitigating natural hazards: Stationarity is immortal!, Water Resour. Res., 50, 9748-9756, doi:10.1002/2014WR016092, 2014.

Nikanorov, A. M., Ivanov, V. V., and Bryzgalo, V. A.: The rivers of the Russian Arctic, the current conditions under the human impact, NOC, Rostov-on-Don, 2007.

Pachauri, R. K. and Reisinger, A. (Eds.): Synthesis Report, Contribution of Working Groups I, II and III to the Fourth Assessment Report of the Intergovernmental Panel on Climate Change, IPCC, Geneva, 2007.

Petrowiki: http://petrowiki.org/Prudhoe_Bay_field, last access: 25 April 2017.

Prowse, T., Bring, A., Mård, J., Carmack, E., Holland, M., Instanes, A., Vihma, T., and Wrona, F. J.: Arctic Freshwater Synthesis: Summary of key emerging issues, J. Geophys. Res.-Biogeo., 120, 1887-1893, doi:10.1002/2015JG003128, 2015.

Pugachev, V. S., Kazakov, I. E., and Evlanov, L. G.: Basics of statistical theory of automatic system, Mashinostroenie, Moscow, 229-234, 1974.

Radionov, V. F. and Fetterer, F.: Meteorological Data from the Russian Arctic 1961-2000, National Snow and Ice Data Center, Boulder, USA, 2003.

Räisänen, J. and Palmer, T. N.: A probability and decisionmodel analysis of a multi model ensemble of climate change situations, J. Climate, 14, 3212-3226, doi:10.1175/15200442(2001)014<3212:APADMA>2.0.CO;2, 2001.

Razuvayev, V. N., Apasova, E.G., Martuganov, R. A., Steurer, P., and Vose, R.: CD-ROM daily temperature and precipitation data for 223 U.S.S.R. stations, ORNL/CDIAC, Oak Ridge National laboratory, Tennessee, 1993.

Roeckner, E., Bäuml, G., Bonaventura, L., Brokopf, R., Esch, M., Giorgett, M., Hagemann, S., Kirchner, I., Kornblueh, L., Manzini, E., Rhodin, A., Schlese, U., Schulzweida, U., and Tompkins, A.: The atmospheric general circulation model ECHAM5. Part I: Model description, Rep. 349, Max Planck Institute for Meteorology, Hamburg, 2003.

Rogdestvenskiy, A. V.: Map of the variation coefficient of the spring flood flow depth (map \#8), in: Atlas of a hydrological maps and nomograms, Gidrometeoizdat, Leningrad, 1986.

Rogdestvenskiy, A. V.: Spatial and temporal variations of river flow in USSR, Gidrometeizdat, Leningrad, 1988.

Rogdestvenskiy, A. V. and Saharyuk, A. V.: Generalization of Student and Fisher criteria for correlated in time and space hydrological timeseries, Lett. State Hydrolog. Inst., 282, 51-71, 1981. 
Serinaldi, F. and Kilsby, C. G.: Stationarity is undead: Uncertainty dominates the distribution of extremes, Adv. Water Resour., 77, 17-36, doi:10.1016/j.advwatres.2014.12.013, 2015.

Shevnina, E. V.: The relationships between an annual and winter precipitation amount and flooding runoff on the rivers over the Russian Arctic, Scient. Rep. Russ. State Hydrometeorol. Univers., 20, 6-12, 2011.

Shevnina, E. V.: The stochastic model validation using observed timeseries: multi-year statistics of spring flood flow depth, Problem Arct. Antarct., 93, 40-50, 2012.

Sillmann, J., Kharin, V. V., Zwiers, F. W., Zhang, X., and Bronaugh, D.: Climate extremes indices in the CMIP5 multimodel ensemble: Part 2, Future climate projections, J. Geophys. Res.-Atmos., 118, 2473-2493, doi:10.1002/jgrd.50188, 2013.

SP33-101-2003: Guideline to estimate the basic hydrological characteristics, Gosstroy, Moscow, 2004.

Spence, C. and Burke, A.: Estimates of Canadian Arctic Archipelago Runoff from Observed Hydrometric Data, J. Hydrol., 362, 247-259, doi:10.1016/j.jhydrol.2008.08.019, 2008.

Taylor, K. E., Stouffer, R. J., and Meehl, G. A.: An overview of CMIP5 and the experiment design, B. Am. Meteorol. Soc., 93, 485-498, doi:10.1175/BAMS-D-11-00094.1, 2012.

Tebaldi, C. and Knutti, R.: The use of the multi-model ensemble in probabilistic climate projections Philos. T. Roy. Soc. A, 365, 2053-2057, doi:10.1098/rsta.2007.2076, 2007.

Thomas, W. J.: A Uniform Technique for Flood Frequency Analysis, J. Water Resour. Pl. Manage., 111, 321-337, doi:10.1061/(ASCE)0733-9496(1985)111:3(321), 1985.
Toreti, A., Naveau, P., Zampieri, M., Schindler, A., Scoccimarro, E., Xoplaki, E., Dijkstra, H. A., Gualdi, S., and Luterbacher, J.: Projections of global changes in precipitation extremes from Coupled Model Intercomparison Project Phase 5 models, Geophys. Res. Lett., 40, 4887-4892, doi:10.1002/grl.50940, 2013.

Veijalainen, N., Lotsari, E., Alho, P., Vehviläinen, B., and Käyhkö, J.: National scale assessment of climate change impacts on flooding in Finland, J. Hydrol., 391, 333-350, doi:10.1016/j.jhydrol.2010.07.035, 2010.

Verzano, K.: Climate change impacts on flood related hydrological processes: further development and application of a global scale hydrological model, Reports on Earth system science 71, Max Planck Institute for Meteorology, Hamburg, 2009.

Viktorova, N. V. and Gromova, M. N.: Long-term forecasting of characteristics of minimal river runoff discharges in Russia in case of possible climate change, Russ. Meteorol. Hydrol., 33, 388-393, doi:10.3103/S1068373908060071, 2008.

Vodogretskiy, V.: Map of the mean values of the spring flood flow depth (map \#6), in: Atlas of a hydrological maps and nomograms, Gidrometeoizdat, Leningrad, 1986.

von Salzen, K., Scinocca, J. F., McFarlane, N. A., Li, J., Cole, J. N. S., Plummer, D., Verseghy, D., Reader, M. C., Ma, X., Lazare, M., and Solheim, L.: The Canadian Fourth Generation Atmospheric Global Climate Model (CanAM4). Part I: Representation of Physical Processes, Atmos.-Ocean, 51, 104-125, doi:10.1080/07055900.2012.755610, 2013. 